\title{
Nitrate radical oxidation of $\gamma$-terpinene: hydroxy nitrate, total organic nitrate, and secondary organic aerosol yields
}

\author{
Jonathan H. Slade ${ }^{1}$, Chloé de Perre ${ }^{2}$, Linda Lee ${ }^{2}$, and Paul B. Shepson ${ }^{1,3}$ \\ ${ }^{1}$ Department of Chemistry, Purdue University, West Lafayette, IN 47907, USA \\ ${ }^{2}$ Department of Agronomy, Purdue University, West Lafayette, IN 47907, USA \\ ${ }^{3}$ Department of Earth, Atmospheric, and Planetary Sciences, Purdue University, West Lafayette, IN 47907, USA \\ Correspondence to: Jonathan H. Slade (jslade@ purdue.edu)
}

Received: 17 March 2017 - Discussion started: 27 March 2017

Revised: 11 June 2017 - Accepted: 13 June 2017 - Published: 17 July 2017

\begin{abstract}
Polyolefinic monoterpenes represent a potentially important but understudied source of organic nitrates (ONs) and secondary organic aerosol (SOA) following oxidation due to their high reactivity and propensity for multi-stage chemistry. Recent modeling work suggests that the oxidation of polyolefinic $\gamma$-terpinene can be the dominant source of nighttime $\mathrm{ON}$ in a mixed forest environment. However, the ON yields, aerosol partitioning behavior, and SOA yields from $\gamma$-terpinene oxidation by the nitrate radical $\left(\mathrm{NO}_{3}\right)$, an important nighttime oxidant, have not been determined experimentally. In this work, we present a comprehensive experimental investigation of the total (gas + particle) ON, hydroxy nitrate, and SOA yields following $\gamma$-terpinene oxidation by $\mathrm{NO}_{3}$. Under dry conditions, the hydroxy nitrate yield $=4(+1 /-3) \%$, total ON yield $=14(+3 /-2) \%$, and SOA yield $\leq 10 \%$ under atmospherically relevant particle mass loadings, similar to those for $\alpha$-pinene $+\mathrm{NO}_{3}$. Using a chemical box model, we show that the measured concentrations of $\mathrm{NO}_{2}$ and $\gamma$-terpinene hydroxy nitrates can be reliably simulated from $\alpha$-pinene $+\mathrm{NO}_{3}$ chemistry. This suggests that $\mathrm{NO}_{3}$ addition to either of the two internal double bonds of $\gamma$-terpinene primarily decomposes forming a relatively volatile keto-aldehyde, reconciling the small SOA yield observed here and for other internal olefinic terpenes. Based on aerosol partitioning analysis and identification of speciated particle-phase ON applying high-resolution liquid chromatography-mass spectrometry, we estimate that a significant fraction of the particle-phase $\mathrm{ON}$ has the hydroxy nitrate moiety. This work greatly contributes to our understanding of ON and SOA formation from polyolefin monoterpene oxidation, which could be important in the northern conti-
\end{abstract}

nental US and the Midwest, where polyolefinic monoterpene emissions are greatest.

\section{Introduction}

The oxidation of volatile organic compounds (VOCs) is a major pathway in the production of secondary organic aerosol (SOA), which can represent up to $\sim 60 \%$ of the total submicron aerosol mass, depending on location (Hallquist et al., 2009; Riipinen et al., 2012; Glasius and Goldstein, 2016). Aerosols impact climate by scattering and absorbing radiation as well as modifying cloud optical properties, and can adversely affect human health (Stocker et al., 2013). A large fraction of the total OA budget derives from the oxidation of biogenic VOCs (BVOCs), including isoprene $\left(\mathrm{C}_{5} \mathrm{H}_{8}\right)$ and monoterpenes $\left(\mathrm{C}_{10} \mathrm{H}_{16}\right)$ (Hallquist et al., 2009; Spracklen et al., 2011). Together, these naturally emitted compounds account for $\sim 60 \%$ of the global BVOC budget (Goldstein and Galbally, 2007; Guenther et al., 1995). In particular, monoterpenes, comprising $\sim 11 \%$ of the total global BVOC emissions (Guenther, 2002), represent a viable source of SOA following oxidation (Griffin et al., 1999; Lee et al., 2006). However, atmospheric models routinely underestimate the global SOA burden (Kokkola et al., 2014), causing a potential order of magnitude error when predicting global aerosol forcing (Goldstein and Galbally, 2007), and thus the sources and mechanisms responsible for SOA formation require further study.

VOC oxidation produces an array of semi-volatile organic aerosol precursors, including organic nitrates $\left(\mathrm{RONO}_{2}\right)$, 
herein referred to as $\mathrm{ONs}$, in the presence of $\mathrm{NO}_{x}$ (i.e., $\mathrm{NO}+\mathrm{NO}_{2}$; Kroll and Seinfeld, 2008; Rollins et al., 2010b, 2012; Darnall et al., 1976). By sequestering $\mathrm{NO}_{x}$, ON can perturb ozone concentrations globally (Squire et al., 2015). Moreover, as $\mathrm{NO}_{x}$ concentrations are expected to decrease in the future (von Schneidemesser et al., 2015), ambient concentrations of $\mathrm{NO}_{x}$ and thus $\mathrm{O}_{3}$ will become increasingly sensitive to ON formation (Tsigaridis and Kanakidou, 2007). Monoterpenes contribute significantly to the formation of $\mathrm{ON}$ and SOA, especially during nighttime in the presence of nitrate radicals $\left(\mathrm{NO}_{3}\right)$, when isoprene concentrations are negligible and the photolytic and $\mathrm{NO}$ reaction sinks of $\mathrm{NO}_{3}$ are cut off (see $\mathrm{Ng}$ et al., 2017, and references therein). It is estimated that monoterpene oxidation by $\mathrm{NO}_{3}$ may account for more than half of the monoterpene-derived SOA in the US, suggesting that $\mathrm{ON}$ is a dominant SOA precursor (Pye et al., 2015). However, their formation mechanisms and yields following oxidation by $\mathrm{NO}_{3}$ are not as well constrained as those from $\mathrm{OH}$ and $\mathrm{O}_{3}$ oxidation (Hoyle et al., 2011), and previous studies have focused on the $\mathrm{NO}_{3}$ oxidation of only a few monoterpenes (Fry et al., 2014), but almost exclusively on mono-olefinic terpenes such as $\alpha$ - and $\beta$-pinene (Boyd et al., 2015; Spittler et al., 2006; Wangberg et al., 1997; Fry et al., 2009; Berkemeier et al., 2016). An important detail is the relative amount of hydroxy nitrates produced, as the $-\mathrm{OH}$ group contributes greatly to water solubility (Shepson et al., 1996), and uptake into aqueous aerosol followed by continuing chemistry in the aqueous phase, which can be an important mechanism for SOA production (Carlton and Turpin, 2013).

A major challenge regarding our understanding of SOA formation from monoterpene oxidation is that there are several isomers of monoterpenes with very different structural characteristics that can exhibit very different yields of SOA following oxidation (Fry et al., 2014; Ziemann and Atkinson, 2012). For example, the SOA mass yield from the $\mathrm{NO}_{3}$ oxidation of $\alpha$-pinene, which contains one endocyclic double bond, is $\sim 0 \%$ under atmospherically relevant particle mass loadings, whereas that from $\beta$-pinene, which contains one terminal double bond, is $33 \%$ under the same experimental conditions (Fry et al., 2014). Limonene, with one tertiary endocyclic and one terminal exocyclic double bond, also exhibits relatively larger SOA mass yields following oxidation by $\mathrm{NO}_{3}$ (Fry et al., 2014; Spittler et al., 2006). Because $\mathrm{NO}_{3}$ oxidation of $\alpha$-pinene primarily leads to tertiary peroxy radical formation (Wangberg et al., 1997), the initially formed alkoxy radical rearranges into a ketone and decomposes the nitrooxy group, releasing $\mathrm{NO}_{2}$ and forming a keto-aldehyde, which has higher saturation vapor pressure compared to its ON analogue (Pankow and Asher, 2008). However, decomposition of the nitrate is not exclusive for all tertiary alkoxy radicals following $\mathrm{NO}_{3}$ oxidation as it may also depend on the structure of the adjacent bond. Based on structureactivity relationships, a $\beta$-alkyl substitution is expected to destabilize the adjacent bond more than a $\beta$-nitrate substitu- tion (Vereecken and Peeters, 2009). In the case of $\beta$-pinene or sabinene, for example, the expected decomposition pathway of the alkoxy radical leaves the nitrooxy group intact to form a keto-nitrate (Fry et al., 2014). SOA yields have also been shown to be strongly dependent on the total (gas + particle) yield of ON. Owing to their low saturation vapor pressures, multifunctional $\mathrm{ON}$ such as the hydroxy nitrates are thought to contribute significantly to SOA formation (Rollins et al., 2010a, b; Lee et al., 2016), and have been the focus of several laboratory and field research campaigns including the BEACHON 2011 field study in the Colorado Front Range (Fry et al., 2013), the BEARPEX 2009 study at the Blodgett forest site in the western foothills of the Sierra Nevada (Beaver et al., 2012), the PROPHET and SOAS field studies in the upper Midwest and southeastern US (Xiong et al., 2015; Lee et al., 2016; Grossenbacher et al., 2004), and the Focused Isoprene eXperiment at the California Institute of Technology (FIXCIT; Nguyen et al., 2014). These ONs can rapidly undergo aqueous-phase processing, especially under acid-catalyzed conditions, to form diols and organosulfates (Jacobs et al., 2014; Rindelaub et al., 2015, 2016; Surratt et al., 2008), which not only complicates quantification of organic nitrates in the aerosol phase (Russell et al., 2011) but also affects product saturation vapor pressure and thus aerosol formation, represents a sink for $\mathrm{NO}_{x}$, and may affect the hygroscopic properties of organic aerosol (Suda et al., 2014). However, considering there are only a limited number of studies that have specifically investigated the yield of hydroxy nitrates, namely following $\mathrm{OH}$ and $\mathrm{NO}_{3}$ oxidation of isoprene (Chen et al., 1998; Lockwood et al., 2010; Xiong et al., 2015) and $\alpha$-pinene (Rindelaub et al., 2015; Wangberg et al., 1997), further measurements of their yields and role in aerosol formation from the oxidation of other terpenoids is critical.

In the southeastern US, $\alpha$ - and $\beta$-pinene tend to dominate monoterpene emissions (Geron et al., 2000), and their potential for ON and SOA formation are better studied compared to other monoterpenes (Ayres et al., 2015; Lee et al., 2016). However, in other regions of the US, polyolefinic monoterpenes such as terpinene, ocimene, and limonene can be present in much greater proportions than in the southeastern US, which may be in part due to the relatively smaller abundance of the $\alpha$ - and $\beta$-pinene emitter southern pine, but also due to the presence of more polyolefinic monoterpene emitters, including Juniperus scopulorum, a common cedar and $\gamma$-terpinene emitter in the US Midwest (Geron et al., 2000). In particular, model simulations suggest that the oxidation of $\gamma$-terpinene, comprising two substituted endocyclic double bonds, can contribute as much as $\alpha$ - and $\beta$-pinene to nighttime organic nitrate production in a mixed northern hardwood forest (Pratt et al., 2012). Those authors also showed that $\mathrm{NO}_{3}$ reaction with BVOCs is important in the daytime. However, the $\mathrm{ON}$ and $\mathrm{SOA}$ yields following $\mathrm{NO}_{3}$ oxidation of $\gamma$-terpinene have not been determined in laboratory studies. 
Here we present a comprehensive laboratory investigation of the hydroxy nitrate, total gas- and particle-phase ON, and $\mathrm{SOA}$ yields from the $\mathrm{NO}_{3}$ oxidation of $\gamma$-terpinene. For the hydroxy nitrate yield experiments, a surrogate standard compound was synthesized as presented in the supplemental information of Rindelaub et al. (2016), enabling quantitative determination of its yield using a chemical ionization mass spectrometer (CIMS). This work contributes to a broader understanding of SOA formation from the oxidation of polyolefinic monoterpenes, and the role of $\mathrm{NO}_{3}$ oxidation chemistry in the sequestration of $\mathrm{NO}_{x}$.

\section{Methods}

Yield experiments were conducted in a $5500 \mathrm{~L}$ photochemical reaction chamber with Teflon walls and perfluoroalkoxycoated endplates, in the dark (Chen et al., 1998). Briefly, the chamber was cleaned by flushing several times with ultrazero (UZ) air in the presence of ultraviolet light. Experiments were conducted in a dry atmosphere (relative humidity $<1 \%$ ) and at ambient temperature $(\sim 295 \mathrm{~K})$. A total of 13 independent yield experiments were conducted over a range of initial $\gamma$-terpinene concentrations in the presence of $\mathrm{N}_{2} \mathrm{O}_{5}$ with and without $\left(\mathrm{NH}_{4}\right)_{2} \mathrm{SO}_{4}$ seed particles. $\mathrm{N}_{2} \mathrm{O}_{5}$ was produced in a dried glass vessel and crystallized at $195 \mathrm{~K}$ in a custom-made glass trap following thermal equilibrium with $\mathrm{NO}_{2}$ and $\mathrm{O}_{3}$, as indicated in Reactions (R1) and (R2) below.

$\mathrm{O}_{3}+\mathrm{NO}_{2} \rightarrow \mathrm{NO}_{3}+\mathrm{O}_{2}$

$\mathrm{NO}_{3}+\mathrm{NO}_{2} \leftrightarrow \mathrm{N}_{2} \mathrm{O}_{5}$

First, the BVOC was transferred to the chamber with UZ air via injection through a heated glass inlet and polytetrafluoroethylene (PTFE) line. For the seeded experiments, $\left(\mathrm{NH}_{4}\right)_{2} \mathrm{SO}_{4}$ particles were generated by passing an aqueous solution through a commercial atomizer (model 3076, TSI, Inc.) and subsequently dried through a diffusion dryer prior to entering the reaction chamber. The seed particles were polydisperse with a range in the geometric mean diameter, $D_{\mathrm{p}, \mathrm{g}}$, of 57 to $94 \mathrm{~nm}$ and geometric standard deviation, $\sigma_{\mathrm{g}}$, of 1.39 to 1.91 . Total seed number and mass concentrations were in the range of $0.61-5.15 \times 10^{4} \mathrm{~cm}^{-3}$ and $8-48 \mu \mathrm{g} \mathrm{m}^{-3}$, respectively, assuming a seed particle density of $1.7 \mathrm{~g} \mathrm{~cm}^{-3}$. Yield experiments were initiated (time $=0$ ) by injecting $\mathrm{N}_{2} \mathrm{O}_{5}$ into the chamber with a flow of UZ air over the crystalline $\mathrm{N}_{2} \mathrm{O}_{5}$. The reactants were allowed to mix continuously in the chamber with a fan, and the reaction was terminated when no less than $10 \%$ of the $\gamma$-terpinene remained to limit secondary particle-phase or heterogeneous $\mathrm{NO}_{3}$ chemistry.

Real-time measurements were made using several instruments: $\gamma$-terpinene concentrations were measured with a gas chromatograph-flame ionization detector (GC-FID; HP5890 Series II), which was calibrated using a commercial $\gamma$ terpinene standard dissolved in cyclohexane. $\mathrm{NO}_{2}$ concen- trations were measured with a custom-built chemiluminescence $\mathrm{NO}_{x}$ analyzer (Lockwood et al., 2010), and a scanning mobility particle sizer (SMPS; model 3062, TSI, Inc.) was used to determine size-resolved particle mass concentrations. No direct concentration measurements of $\mathrm{NO}_{3}$ were made. The hydroxy nitrates were measured online continuously using an iodide-adduct chemical ionization mass spectrometer (CIMS; Xiong et al., 2015, 2016). To quantify the production of monoterpene hydroxy nitrates, the CIMS was calibrated with a purified standard of an $\alpha$-pinene-derived hydroxy nitrate synthesized in-house via nitrification of $\alpha$ pinene oxide (Sigma-Aldrich, $97 \%$ ) using $\mathrm{Bi}\left(\mathrm{NO}_{3}\right)_{3} \cdot 5 \mathrm{H}_{2} \mathrm{O}$ (Rindelaub et al., 2016). The concentration of the purified hydroxy nitrate was verified via two complementary methods: proton nuclear magnetic resonance $\left({ }^{1} \mathrm{HNMR}\right)$ and Fourier transform infrared spectroscopy (FTIR), and the structure was verified using ${ }^{13} \mathrm{C}-\mathrm{NMR}$, as presented in the supplementary information of Rindelaub et al. (2016). The total ON yields and concentration of the standard were determined via FTIR measurement of the asymmetric $-\mathrm{NO}_{2}$ stretch located at $\sim 1640 \mathrm{~cm}^{-1}$ using tetrachloroethylene (Sigma-Aldrich, HPLC grade, $\geq 99.9 \%$ ) as the solvent (Rindelaub et al., 2015). We note that the FTIR approach cannot distinguish mono-nitrated from poly-nitrated organics. However, given the relatively low concentrations of $\mathrm{NO}_{2}$ compared to $\mathrm{O}_{2}$ in the chamber and their rate constants with alkoxy radicals (Atkinson et al., 1982), first-generation dinitrates constitute an insignificant fraction of $\mathrm{ON}(<0.2 \%)$. Second-generation dinitrates from $\mathrm{NO}_{3}$ reaction at the remaining double bond on $\gamma$-terpinene, however, may account for a maximum of $\sim 10 \%$ of the total $\mathrm{ON}$ based on the relative rates of primaryto-secondary monoterpene oxidation reactions. Thus the uncertainties for our reported yields include a component from this uncertainty $(10 \%)$ in the fraction of the nitrates that are dinitrates. The total gas-phase $\mathrm{ON}$ yields were determined with FTIR following the sampling of chamber air through an annular denuder (URG-200) coated with XAD-4 resin and extraction from the denuder walls with tetrachloroethylene as in a previous study (Rindelaub et al., 2015). Aerosol particles were collected on $47 \mathrm{~mm}$ PTFE filters ( $1 \mu \mathrm{m}$ pore size; $\sim 100 \%$ collection efficiency) housed in a cartridge connected to the denuder exit. The collection efficiency of the denuder walls for gas-phase organic nitrates was determined to be $>98 \%$ based on measurements of the concentration of 2-ethyl-hexyl-nitrate (Sigma-Aldrich, $97 \%$ ) before and after the denuder with the GC-FID. The particle transmission efficiency was determined to be $>98 \%$ by measuring the number concentration of particles before and after the denuder with the SMPS.

Wall loss and dilution corrections were applied to both the SOA and ON yields accounting for the time required to sample through the denuder. Following several of the experiments, the SOA concentration was measured as a function of reaction time with the wall with an average wall loss rate constant, $k_{\mathrm{wall}, \mathrm{SOA}}=9 \times 10^{-5} \mathrm{~s}^{-1}$. The gas- 
phase ON wall loss rate was determined based on the evolution of the CIMS-derived monoterpene hydroxy nitrate $\left(M=\mathrm{C}_{10} \mathrm{H}_{17} \mathrm{NO}_{4}\right)$ signal $\left([M+I]^{-} ; m / z=342\right)$ following an experiment, in which we obtained $k_{\mathrm{ONg}}=2 \times 10^{-5} \mathrm{~s}^{-1}$, as shown in Fig. S1 in the Supplement.

Selected filter extracts from two separate chamber experiments were analyzed for their chemical composition via ultra-performance liquid chromatography electrospray ionization time-of-flight tandem mass spectrometry (UPLCESI-ToF-MS/MS, Sciex 5600+ TripleToF with Shimadzu 30 series pumps and autosampler) to identify potential ON species in the particle phase from $\gamma$-terpinene oxidation by $\mathrm{NO}_{3}$. The samples were first dried with ultra-high-purity nitrogen and then extracted with a $1: 1 v: v$ solvent mixture of HPLC-grade methanol and $0.1 \%$ acetic acid in nanopure $\mathrm{H}_{2} \mathrm{O}$, which has been used successfully as a solvent system for identifying multifunctional organonitrate and organosulfate species (Surratt et al., 2008).

\section{Results and discussion}

\subsection{SOA yields}

Mass-dependent SOA yields ( $\left.Y_{\mathrm{SOA}}\right)$ were derived from both seeded and unseeded experiments and defined here as the change in aerosol mass concentration $\left(\Delta M\right.$ in $\left.\mu \mathrm{g} \mathrm{m}^{-3}\right)$ relative to the concentration of BVOC consumed $(\triangle \mathrm{BVOC}$ in $\mu \mathrm{g} \mathrm{m}^{-3}$ ), i.e., $Y_{\mathrm{SOA}}=\Delta M / \Delta \mathrm{BVOC}$. $\Delta M$ was derived from individual SOA growth curves as shown in Fig. 1. Here the initial mass is defined as the average SMPS-derived particle mass in the chamber prior to $\mathrm{N}_{2} \mathrm{O}_{5}$ injection, and the final mass is derived from the maximum of the SOA growth curve when $\triangle B V O C$ stabilizes, as shown in Fig. S2. Note that under these experimental conditions, SOA formation occurs rapidly, limited on the short end by the thermal decomposition $e$-folding lifetime of $\mathrm{N}_{2} \mathrm{O}_{5}(\sim 30 \mathrm{~s}$ at $295 \mathrm{~K})$ and the $e$-folding lifetime of $\mathrm{NO}_{3}$ reaction with $\gamma$ terpinene (few milliseconds assuming a rate constant of $2.9 \times 10^{-11} \mathrm{~cm}^{3}$ molecule ${ }^{-1} \mathrm{~s}^{-1}$ ), and on the long end by the timescale for heterogeneous uptake of $\mathrm{N}_{2} \mathrm{O}_{5}$ of several hours assuming an uptake coefficient at low relative humidity of $10^{-4}$ (Abbatt et al., 2012).

Values of $Y_{\text {SOA }}$ with and without seed particles as a function of particle mass loading are depicted in Fig. 2. The curve shows that under low mass loadings, the yields are less than under high mass loadings, indicative of absorptive partitioning (Hao et al., 2011; Odum et al., 1996). To model the measured $Y_{\mathrm{SOA}}$ as a function of particle mass loading, we apply an absorptive partitioning model following the method of Odum et al. (1996), as shown in Eq. (1).

$Y_{\mathrm{SOA}}=M_{0} \sum_{i}\left(\frac{\alpha_{i} K_{\mathrm{om}, i}}{1+K_{\mathrm{Om}, i} M_{0}}\right)$

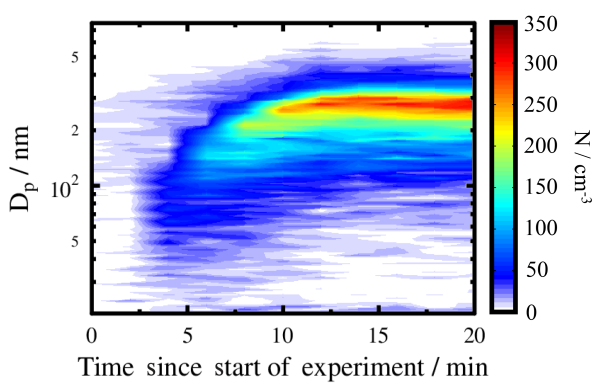

Figure 1. Example wall-loss-corrected SOA growth curve for $\gamma$ terpinene $+\mathrm{NO}_{3}$ in the absence of seed aerosol. The color scale represents aerosol number concentration, $N\left(\mathrm{~cm}^{-3}\right)$.

Here, $\alpha_{i}$ is a proportionality constant describing the fraction of product $i$ in the aerosol phase, $M_{0}$ is the aerosol mass concentration, and $K_{\mathrm{om}, i}$ is the absorptive partitioning coefficient of the absorbing material. Assuming a two-product model, the best fit values are $\alpha_{1}=0.94, K_{\mathrm{om}, 1}=7.9 \times 10^{-4}$, $\alpha_{2}=0.33$, and $K_{\mathrm{om}, 1}=2.6 \times 10^{-2}$. Extending this model to a conservative ambient mass loading of $10 \mu \mathrm{g} \mathrm{m}^{-3}$, characteristic of biogenic SOA-impacted environments (Fry et al., 2014 ), the SOA yield is $\sim 10 \%$. We caution that the model is not very well constrained at low mass loadings due to the limited number of data points below $30 \mu \mathrm{g} \mathrm{m}^{-3}$. From the $95 \%$ confidence intervals, a conservative estimate of the relative uncertainty in the yield at $10 \mu \mathrm{g} \mathrm{m}^{-3}$ is $+100 /-50 \%$. In contrast, at mass loadings $>500 \mu \mathrm{g} \mathrm{m}^{-3}$, which is more relevant in highly polluted urban areas such as those along the coast of India (Bindu et al., 2016), $Y_{\text {SOA }}$ can be as large as $\sim 50 \%$. For comparison, $Y_{\mathrm{SOA}}$ of other reaction systems applying the absorptive partitioning values derived from those experiments are plotted along with our experimental data in Fig. 2. The $\gamma$-terpinene $+\mathrm{NO}_{3} Y_{\mathrm{SOA}}$ are significantly less than those involving $\beta$-pinene, an important contributor to SOA formation predominately in the southeastern US (Boyd et al., 2015). However, at relatively low particle mass loadings, $Y_{\mathrm{SOA}}$ for $\mathrm{NO}_{3}+\gamma$-terpinene is comparable to those derived from the $\mathrm{OH}$ oxidation of $\gamma$-terpinene and $\alpha$-pinene (Griffin et al., 1999; Lee et al., 2006). Interestingly, our measured $Y_{\mathrm{SOA}}$ at comparable mass loadings are also within the reported range of $Y_{\mathrm{SOA}}$ from the $\mathrm{NO}_{3}$ oxidation of $\alpha$-pinene of $0-16 \%$ (see Fry et al., 2014, and references therein), which are relatively small compared to other monoterpene + $\mathrm{NO}_{3}$ reaction systems, which range from $13 \%$ to $65 \%$ for $\beta$ pinene, limonene, and $\delta$-3-carene ( $\mathrm{Ng}$ et al., 2017). The studies reporting low $Y_{\mathrm{SOA}}$ also report relatively low $\mathrm{ON}$ yields and high ketone yields, suggesting that the $\mathrm{NO}_{3}$ oxidation products of $\alpha$-pinene, and likely $\gamma$-terpinene, lose the nitrate moiety and hence are sufficiently volatile and do not contribute significantly to SOA formation under atmospherically relevant aerosol mass loadings. In contrast, the experiments reporting higher $Y_{\mathrm{SOA}}$ report relatively greater $\mathrm{ON} /$ ketone yield ratios, with the exception of sesquiterpenes such as $\beta$ - 

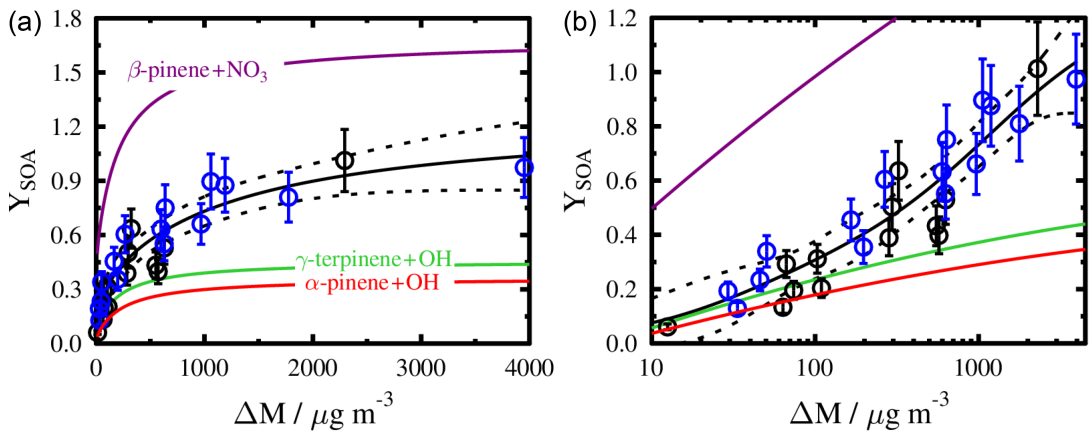

Figure 2. Change in aerosol mass concentration $(\Delta M)$ and wall-loss-corrected SOA yields $\left(Y_{\mathrm{SOA}}\right)$ from the $\mathrm{NO}_{3}$ oxidation of $\gamma$-terpinene in unseeded (black circles) and $\left(\mathrm{NH}_{4}\right)_{2} \mathrm{SO}_{4}$-seeded experiments (blue circles). The data were fitted to a two-product absorptive partitioning model (black curve) and the dashed curves represent the $95 \%$ confidence intervals of the fitting function. For comparison, the mass-dependent yield curves of $\alpha$-pinene and $\gamma$-terpinene in the presence of $\mathrm{OH}$ are shown in the red and green curves, respectively, and $\beta$-pinene $+\mathrm{NO}_{3}$ in purple (Griffin et al., 1999; Lee et al., 2006). For clarity, (b) shows (a) data on a log scale.

caryophyllene, suggesting ONs are important aerosol precursors.

\subsection{Organic nitrate yields}

ON can partition to the particle phase and contribute to SOA formation and mass growth. However, measurements of their yields are limited and highly variable depending on the composition of the reactive organic species and the type of oxidant (Ziemann and Atkinson, 2012). Here we report the measured gas- and aerosol-phase ON yields, and the total (sum of gas and aerosol ON) yield following $\gamma$-terpinene oxidation by $\mathrm{NO}_{3}$. The $\mathrm{ON}$ yields $\left(Y_{\mathrm{ON}}\right)$ are defined as the concentration of ON produced $(\triangle \mathrm{ON})$ either in the gas or particle phases, relative to the concentration of BVOC consumed, $\Delta \mathrm{BVOC}$, i.e., $Y_{\mathrm{ON}}=\Delta \mathrm{ON} / \Delta \mathrm{BVOC}$. In these experiments, $\triangle B V O C$ was varied systematically by altering the concentration of $\mathrm{N}_{2} \mathrm{O}_{5}$ added to the chamber and monitoring the change in BVOC concentration with the GC-FID. These experiments were conducted both in the presence and absence of $\left(\mathrm{NH}_{4}\right)_{2} \mathrm{SO}_{4}$ seed aerosol particles and under dry conditions, and corrected for wall losses and dilution.

\subsubsection{Total gas-phase organic nitrate yield}

As indicated in Fig. 3, the concentration of total gas-phase $\mathrm{ON}\left(\mathrm{ON}_{\mathrm{g}}\right.$; determined via FT-IR) increases linearly as a function of $\triangle \mathrm{BVOC}$, independent of the presence or absence of the seed aerosol. By fitting both the unseeded and seeded data using linear regression, we derive a gas-phase molar $\mathrm{ON}$ yield $\left(Y_{\mathrm{ONg}}\right)$ of $11( \pm 1) \%$, where the relative uncertainty in the yield of $\sim 9 \%$ is derived from the $95 \%$ confidence intervals (shown in dashed lines in Fig. 3) of the linear fit to the data, and accounting for the measurement uncertainties, shown as error bars. The similar yields with or without seed particles imply that after some uptake, the two cases might appear identical to the adsorbing molecules. Some of the variability in the yield presented in Fig. 3, particularly below $\triangle \mathrm{BVOC} \sim 300 \mathrm{ppb}$, may be attributed to greater relative uncertainty in $\triangle \mathrm{ON}$ and $\triangle \mathrm{BVOC}$ for low extents of $\mathrm{BVOC}$ reaction, different concentrations of $\mathrm{NO}_{2}$ in the chamber, and differences in the time frame of the experiment, as indicated in Table 1. While some wall loss of the lowervolatility multifunctional oxidation products could bias the reported yields low (Zhang et al., 2014), the effects of wall loss on the yield of $\mathrm{ON}$ are accounted for in these experiments and are minimal ( $<5 \%$ correction to the yield), given our relatively short experimental timescales ( $\sim 40 \mathrm{~min}$ on average) and measured wall loss rate of the hydroxy nitrate of $\sim 10^{-5} \mathrm{~s}^{-1}$. As noted in the methods section, secondary oxidation of the remaining double bond of $\gamma$-terpinene may account for $\sim 10 \%$ of the uncertainty in $Y_{\mathrm{ONg}}$. Regardless, $Y_{\mathrm{ONg}}$ observed here for $\gamma$-terpinene is considerably smaller than those measured from the $\mathrm{NO}_{3}$ oxidation of limonene and $\beta$-pinene, but very similar to the yield from $\mathrm{NO}_{3}$ oxidation of $\alpha$-pinene (Fry et al., 2014).

\subsubsection{Total particle-phase organic nitrate yield}

In general, particle-phase $\mathrm{ON}$ concentrations $\left(\mathrm{ON}_{\mathrm{p}}\right)$ increase with increasing $\triangle \mathrm{BVOC}$ as shown in Fig. 4, with a particlephase ON yield $\left(Y_{\mathrm{ONp}}\right)$ from the slope of $3( \pm 1) \%$. Since there were no significant differences in $\mathrm{ON}_{\mathrm{p}}$ between experiments conducted with and without seed aerosol, the slope (i.e., yield) is derived from a fit to both data sets. The insignificant difference in the particle-phase ON yields between the seeded and unseeded experiments may be due to the large fraction of organic material in the particles in both cases, and for the seeded experiments, relative to sulfate. During both the seeded and unseeded experiments, on average particle mass increased by orders of magnitude following uptake of the oxidation products. Thus, in terms of uptake from the gas phase, and component solubility, for example, the particles in the two cases are effectively identical. $Y_{\mathrm{ONp}}$ can be affected by wall loss of both semi-volatile ON products and particles. 
Table 1. Initial conditions and yields from individual experiments. Time indicates the period between $\mathrm{N}_{2} \mathrm{O}_{5}$ addition to the chamber and gas and particle collection by the denuder and filter. "n.m." indicates "not measured".

\begin{tabular}{|c|c|c|c|c|c|c|c|c|c|c|}
\hline $\begin{array}{l}\text { Date } \\
\mathrm{mm} / \mathrm{dd} / \mathrm{yyyy}\end{array}$ & Seed & $\begin{array}{r}\triangle \mathrm{BVOC} / \\
\mathrm{ppb}\end{array}$ & $\begin{array}{r}\Delta \mathrm{ON}_{\mathrm{g}} / \\
\mathrm{ppb}\end{array}$ & $\begin{array}{r}\Delta \mathrm{BVOC} / \\
\mathrm{mol} \times 10^{-4}\end{array}$ & $\begin{array}{r}\Delta \mathrm{ON}_{\mathrm{p}} / \\
\mathrm{mol} \times 10^{-4}\end{array}$ & $\begin{array}{r}{\left[\mathrm{NO}_{2}\right] /} \\
\mathrm{ppb}\end{array}$ & $\begin{array}{r}\text { Time/ } \\
\text { min }\end{array}$ & $Y_{\mathrm{ONg}}$ & $Y_{\mathrm{ONp}}$ & $\begin{array}{r}\Delta M / \\
\mu \mathrm{g} \mathrm{m}^{-3}\end{array}$ \\
\hline 9/9/2015 & None & 229 & 10 & 0.52 & 0.012 & 60 & 52 & $4 \%$ & $2 \%$ & 530 \\
\hline 9/17/2015 & None & 131 & 16 & 0.30 & 0.025 & 31 & 30 & $12 \%$ & $9 \%$ & 272 \\
\hline 9/19/2015 & None & 90 & 7 & 0.20 & 0.017 & 29 & 28 & $7 \%$ & $8 \%$ & 311 \\
\hline $9 / 21 / 2015$ & None & 214 & 15 & 0.48 & 0.007 & 56 & 73 & $7 \%$ & $2 \%$ & 604 \\
\hline $9 / 23 / 2015$ & None & 256 & 21 & 0.58 & 0.017 & 82 & 18 & $8 \%$ & $3 \%$ & 534 \\
\hline $9 / 23 / 2015$ & None & 80 & 8 & 0.18 & 0.007 & 23 & 31 & $10 \%$ & $4 \%$ & 61 \\
\hline $10 / 20 / 2015$ & $\left(\mathrm{NH}_{4}\right)_{2} \mathrm{SO}_{4}$ & 761 & 90 & 1.70 & 0.038 & n.m. & 62 & $12 \%$ & $2 \%$ & 3800 \\
\hline $10 / 22 / 2015$ & $\left(\mathrm{NH}_{4}\right)_{2} \mathrm{SO}_{4}$ & 164 & 31 & 0.37 & 0.035 & n.m. & 48 & $19 \%$ & $9 \%$ & 575 \\
\hline $10 / 28 / 2015$ & $\left(\mathrm{NH}_{4}\right)_{2} \mathrm{SO}_{4}$ & 47 & 9 & 0.11 & 0.002 & 7 & 14 & $18 \%$ & $2 \%$ & 32 \\
\hline $11 / 09 / 2015$ & $\left(\mathrm{NH}_{4}\right)_{2} \mathrm{SO}_{4}$ & 245 & 23 & 0.55 & 0.006 & 54 & 48 & $10 \%$ & $1 \%$ & 1143 \\
\hline $11 / 10 / 2015$ & $\left(\mathrm{NH}_{4}\right)_{2} \mathrm{SO}_{4}$ & 66 & 4.5 & 0.15 & 0.006 & 28 & 32 & $7 \%$ & $4 \%$ & 159 \\
\hline $11 / 12 / 2015$ & None & 413 & 49 & 0.93 & 0.020 & 326 & 45 & $12 \%$ & $2 \%$ & 623 \\
\hline $11 / 18 / 2015$ & None & 408 & 39 & 0.92 & 0.037 & 138 & 35 & $10 \%$ & $4 \%$ & 2206 \\
\hline
\end{tabular}

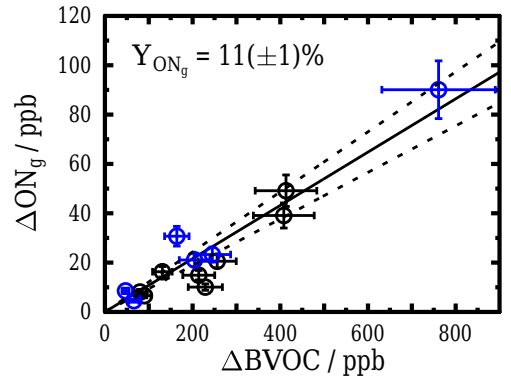

Figure 3. Total wall-loss- and dilution-corrected gas-phase organic nitrate production $(\triangle \mathrm{ON})$ as a function of the amount of BVOC consumed ( $\triangle \mathrm{BVOC}$ ) for the unseeded (black circles) and $\left(\mathrm{NH}_{4}\right)_{2} \mathrm{SO}_{4}$-seeded experiments (blue circles). Horizontal and vertical error bars represent the uncertainty in the GC-FID and FT-IR calibrations, respectively. The black line shows the linear fit of the data through the origin and the dashed lines indicate the $95 \%$ confidence intervals of the fit. The slopes of these lines represent the fractional organic nitrate yield and uncertainty presented in the plot, respectively.

Given our relatively short experimental timescales and relatively large particle / wall surface area ratios (upwards of 0.05) compared to other studies (Nah et al., 2016; Zhang et al., 2014), wall loss corrections amount to an increase in the relative uncertainty of the yield of 8 to $39 \%$. The greater spread in $\mathrm{ON}_{\mathrm{p}}$ compared to $\mathrm{ON}_{\mathrm{g}}$ (see Fig. 3) as a function of $\triangle \mathrm{BVOC}$ may be due to variable chemistry occurring in the particle phase and the greater relative uncertainty in the case of the lower particle-phase yields. It is possible that the presence of some aerosol liquid water and particle acidity, aided by the presence of hygroscopic $\left(\mathrm{NH}_{4}\right)_{2} \mathrm{SO}_{4}$ and uptake of product $\mathrm{HNO}_{3}$ by the particles, could result in relatively lower $\mathrm{ON}_{\mathrm{p}}$ yields, even at low relative humidity (Rindelaub et al., 2015). However, while we did not systematically in-

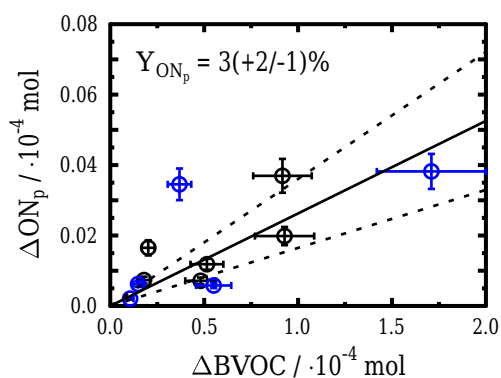

Figure 4. Total wall-loss- and dilution-corrected particle-phase organic nitrate production $\left(\Delta \mathrm{ON}_{\mathrm{p}}\right)$ as a function of the amount of BVOC consumed $(\triangle \mathrm{BVOC})$ for the unseeded (black circles) and $\left(\mathrm{NH}_{4}\right)_{2} \mathrm{SO}_{4}$-seeded experiments (blue circles). The error bars and fits are derived as in Fig. 3.

vestigate the dependence of yields on hydrolysis, we did two experiments that reveal that the ONs produced here are less prone to hydrolysis. Specifically, we found that the gas $(10 \%)$, particle $(1-6 \%)$, and total ON yields $(11-16 \%)$ at a relative humidity of $50 \%$ were within the uncertainty of the yields determined under dry conditions. The expected major ON product shown in the right-hand side of Fig. 5 has a secondary nitrooxy functional group, which has been shown to be less prone to hydrolysis than tertiary nitrooxy groups (Darer et al., 2011). To account for the effects mentioned above, we estimate a more conservative aerosol organic nitrate yield of $3(+2 /-1) \%$, based on the upper limit of the data variability.

\subsection{Organic nitrate aerosol partitioning and effect on SOA yield}

The sum of $\mathrm{ON}_{\mathrm{g}}+\mathrm{ON}_{\mathrm{p}}\left(\mathrm{ON}_{\mathrm{t}}\right)$ is plotted as a function of $\triangle \mathrm{BVOC}$ in Fig. 6 . Together, they result in a total molar ON 


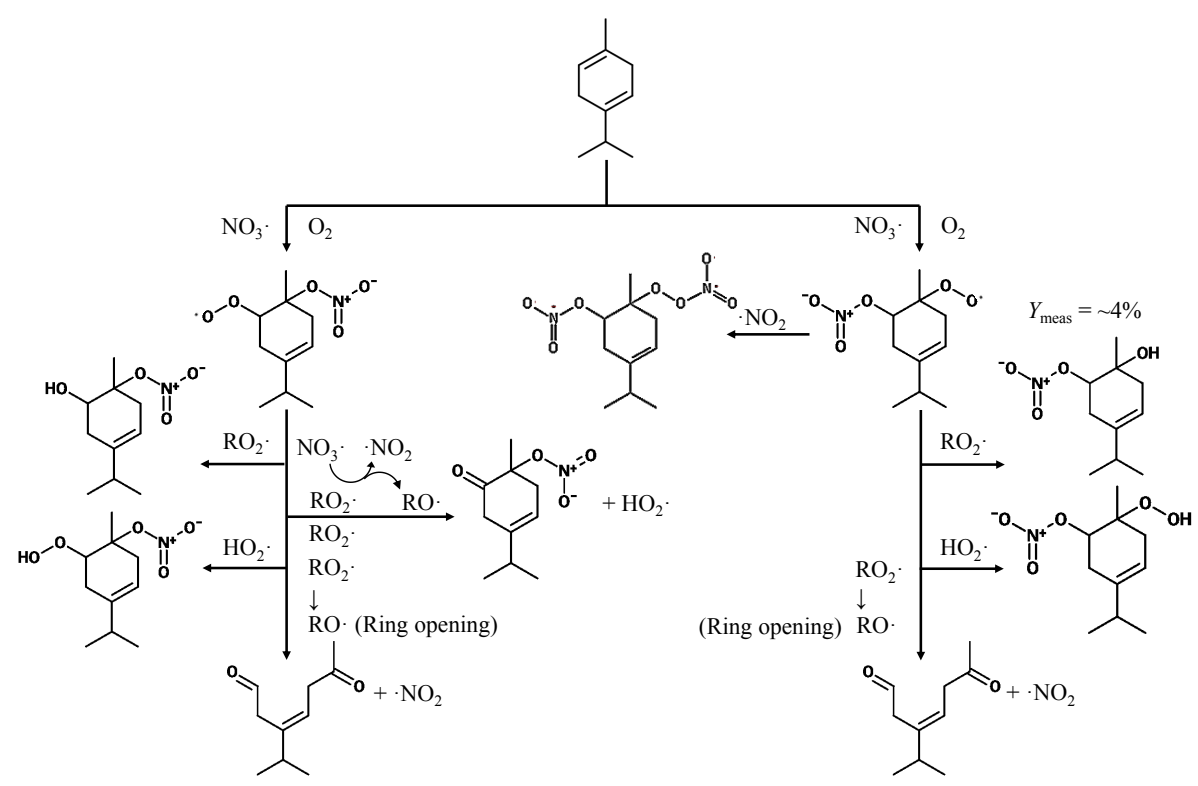

Figure 5. Proposed initial reaction pathways for the $\mathrm{NO}_{3}$ oxidation of $\gamma$-terpinene. For simplicity, only the first-generation oxidation products are shown.

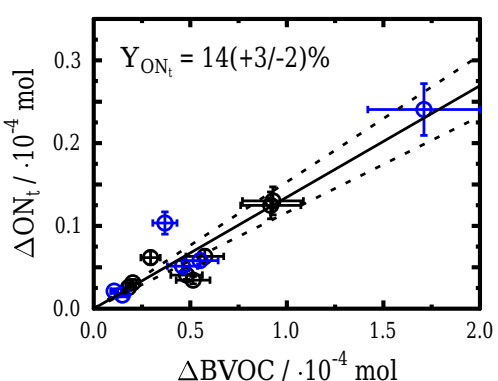

Figure 6. Total wall-loss- and dilution-corrected organic nitrate production $(\triangle \mathrm{ON} \mathrm{t})$ as a function of the amount of BVOC consumed $(\triangle \mathrm{BVOC})$ for the unseeded (black circles) and $\left(\mathrm{NH}_{4}\right)_{2} \mathrm{SO}_{4}$-seeded experiments (blue circles). The error bars and fits are derived as in Fig. 3.

yield, $Y_{\mathrm{ONt}}=14(+3 /-2) \%$, accounting for the potential loss of aerosol-phase $\mathrm{ON}$ as described previously, comparable to previously measured $\mathrm{ON}$ yields from the $\mathrm{NO}_{3}$ oxidation of $\alpha$-pinene of $10 \%$ (Fry et al., 2014) and $14 \%$ (Wangberg et al., 1997). From the ratio $Y_{\mathrm{ONp}} / Y_{\mathrm{ONt}}, \sim 20 \%$ of the total $\mathrm{ON}$ produced from $\gamma$-terpinene $+\mathrm{NO}_{3}$ partitioned to the particle phase, for these relatively high aerosol mass loading conditions. Assuming an average $\mathrm{ON}$ molar mass of $215 \mathrm{~g} \mathrm{~mol}^{-1}$, representing a $\mathrm{C}_{10}$-derived hydroxy nitrate (Rindelaub et al., 2015 ), roughly $14 \%$ of the total aerosol mass is comprised of ON. Gas-to-particle partitioning depends strongly on the molecule's equilibrium saturation vapor pressure and mass transfer kinetics (Shiraiwa and Seinfeld, 2012). The addition of nitrooxy and hydroxy groups, for example, can reduce the equilibrium saturation vapor pressure by several orders of magnitude (Capouet et al., 2008). Molecules with saturation vapor pressures $>10^{-5}$ atm are almost exclusively in the gas phase, whereas those below $10^{-13}$ atm are almost exclusively in the condensed phase (Compernolle et al., 2011). We can estimate the saturation vapor pressure of the $\mathrm{ON}\left(p_{i}^{0}\right)$ based on the estimated $\mathrm{ON}$ aerosol mass fraction $\left(\varepsilon_{i}^{\text {aero }}=0.14\right)$ as given in Eq. (2) (Valorso et al., 2011).

$\varepsilon_{i}^{\mathrm{aero}}=\frac{1}{1+\frac{M_{\mathrm{aero} \gamma} \gamma_{i}^{0}}{C_{\mathrm{aero}} \mathrm{R} T}}$

Here, $M_{\text {aero }}$ is the average particle molar mass, $\gamma_{i}$ is the activity coefficient of molecule " $i$ ", $C_{\text {aero }}$ is the aerosol mass concentration, $R$ is the gas constant, and $T$ is temperature. Assuming ideality, i.e., $\gamma_{i}=1, C_{\text {aero }}=835 \mu \mathrm{g} \mathrm{m}^{-3}$ (average of $\Delta M$ values from experiments listed in Table 1), and $M_{\text {aero }}=$ $215 \mathrm{~g} \mathrm{~mol}^{-1}$, we derive a $p_{i}^{0}$ for $\mathrm{ON}$ of $\sim 6 \times 10^{-7}$ atm or $\log _{10}$ saturation concentration of $\sim 4 \mu \mathrm{g} \mathrm{m}^{-3}$, which for a semivolatile $\mathrm{C}_{10}$-derived hydrocarbon is expected to have between two and four oxygen atoms (Donahue et al., 2011). This estimated $p_{i}^{0}$ for $\mathrm{ON}$ is about an order of magnitude greater than that calculated for the expected tertiary hydroxy and hydroperoxy nitrates of $\gamma$-terpinene shown in Fig. 5 of $6.9 \times 10^{-8}$ and $3.9 \times 10^{-8}$ atm, respectively, using SIMPOL. 1 (Pankow and Asher, 2008), suggesting that the $\mathrm{ON}_{\mathrm{p}}$ products of $\gamma$-terpinene likely comprise a mixture of hydroperoxy and hydroxy nitrates, and other more volatile ON species, likely keto-nitrates, e.g., as shown in Fig. 5 for the case of $\mathrm{NO}_{3}$ addition to the more-substituted carbon. For the keto-nitrate shown in Fig. 5, we calculate a $p_{i}^{0}$ value of $1.4 \times 10^{-6} \mathrm{~atm}$, using SIMPOL.1, roughly a factor of 2 greater than our es- 


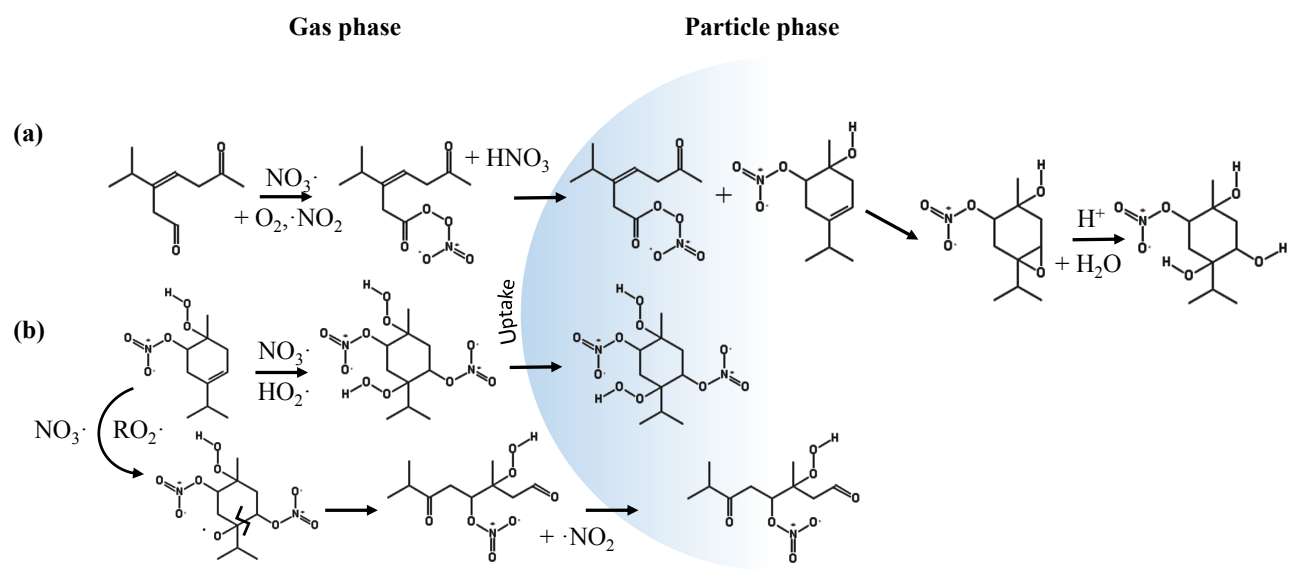

Figure 7. Potential second-generation oxidation reactions and particle-phase chemistry. (a) $\mathrm{NO}_{3}$ oxidation of $\gamma$-terpinaldehyde and olefin epoxidation by peroxy acyl nitrate, followed by acid-catalyzed hydrolysis of the epoxide to form the diol. (b) $\mathrm{RO}_{2} \bullet$ and $\mathrm{HO}_{2} \bullet$ pathways following $\mathrm{NO}_{3}$ oxidation of the first-generation nitrooxy hydroperoxide.

timate for the average for our aerosol. For comparison, the keto-aldehyde presented in Fig. 5 ( $\gamma$-terpinaldehyde) has a $p_{i}^{0}$ value of $0.092 \mathrm{~atm}$, using SIMPOL.1. As presented in the supplementary information, analysis of liquid extracts from filter samples using UPLC-ESI-ToF-MS/MS operated in negative ion mode indicates the presence of masses consistent with the first-generation hydroperoxy nitrate and secondgeneration di-hydroxy dinitrates in the aerosol phase, the latter of which may result from both gas- and heterogeneous reactions that proceed at the unsubstituted olefinic $\mathrm{C}$ of a $\gamma$-terpinene hydroxy nitrate. In the absence of substantial $\mathrm{HO}_{2}$ in our experiments, the dominant pathway for $\mathrm{RO}_{2}$ is likely to follow either $\mathrm{RO}_{2}+\mathrm{NO}_{3}$ or $\mathrm{RO}_{2}+\mathrm{RO}_{2}$ (when [VOC] $\gg \mathrm{N}_{2} \mathrm{O}_{5}$ ). However, in ambient nighttime air there may be substantially more $\mathrm{RO}_{2}+\mathrm{HO}_{2}$ reactions than in our chamber experiments. Isoprene nitrooxy hydroperoxide, for example, has been identified as the major product from isoprene oxidation by the nitrate radical in the presence of $\mathrm{HO}_{2}$ (Schwantes et al., 2015), and organic hydroperoxides have been identified as major SOA products from monoterpene and sesquiterpene ozonolysis (Reinnig et al., 2009; Docherty et al., 2005). Thus our chamber experiments may underestimate the concentration of hydroperoxides formed from $\gamma$-terpinene oxidation by $\mathrm{NO}_{3}$ in the ambient environment. While we did not confirm the presence of epoxides in our experiments, and it is hard to see how an epoxide could form in the dark gas phase in these experiments, the remaining double bond of the first-generation hydroxy nitrate may be susceptible to epoxidation in the particle phase. For example, it is known that peroxyacetyl nitrate (PAN) very efficiently epoxidizes olefins in solution (Darnall and Pitts, 1970). While there would not be PAN as a product in our experiment, there could be very significant yields of the corresponding peroxy acyl nitrate from $\mathrm{NO}_{3}$ reaction with $\gamma$ terpinaldehyde, followed by uptake of that compound into the aerosol phase. As shown in Fig. 7a, that PAN compound could then react with, and produce the corresponding epoxide of any particle-phase compound with a double bond, e.g., the hydroxy nitrate, to produce a $\mathrm{C}_{10} \mathrm{H}_{17} \mathrm{O}_{5}$ product. That epoxide would then undergo $\mathrm{pH}$-dependent hydrolysis in solution to produce the corresponding diol $\left(\mathrm{C}_{10} \mathrm{H}_{18} \mathrm{O}_{6}\right)$ (Jacobs et al., 2014). Applying the Extended Aerosol Inorganics Model (E-AIM; http://www.aim.env.uea.ac.uk/aim/aim. php), we estimate a $\mathrm{pH} \sim 5.5$ for the $\left(\mathrm{NH}_{4}\right)_{2} \mathrm{SO}_{4}$ seed particles under saturated conditions, becoming more acidic as the particles uptake $\mathrm{HNO}_{3}$. It is important to note that the reaction products and their concentrations and thus degree of aerosol partitioning and SOA yields may also be affected by the concentration of $\mathrm{NO}_{3}$ in the chamber. Under very high $\mathrm{NO}_{x}$ conditions as in some of the experiments here, reactions between $\mathrm{RO}_{2}$ and $\mathrm{NO}_{3}$ out-compete those with $\mathrm{HO}_{2}$, which may lead to formation of relatively more volatile carbonyl reaction products, as indicated in Fig. 5, and relative suppression of particle mass. This effect is consistent with other studies that report lower SOA yields in the presence of high $\mathrm{NO}_{x}$ concentrations ( $\mathrm{Ng}$ et al., 2007; Presto et al., 2005; Song et al., 2005). Regardless, an aerosol mass fraction of ON of $14 \%$ is considerably less than that obtained for other monoterpenes reacting with $\mathrm{NO}_{3}$, with the exception of $\alpha$-pinene (Fry et al., 2014). This could be a result of both production of mostly volatile ON species, in particular ketonitrates, and further reaction of the olefinic hydroxy nitrate in the aerosol phase. To verify the potential role of hydroxy nitrates in SOA production from $\mathrm{NO}_{3}+\gamma$-terpinene as well as the presence of other $\mathrm{ON}$, the following section focuses on product identification of gas-phase ON species using CIMS and determination of gas-phase hydroxy nitrate yields. 


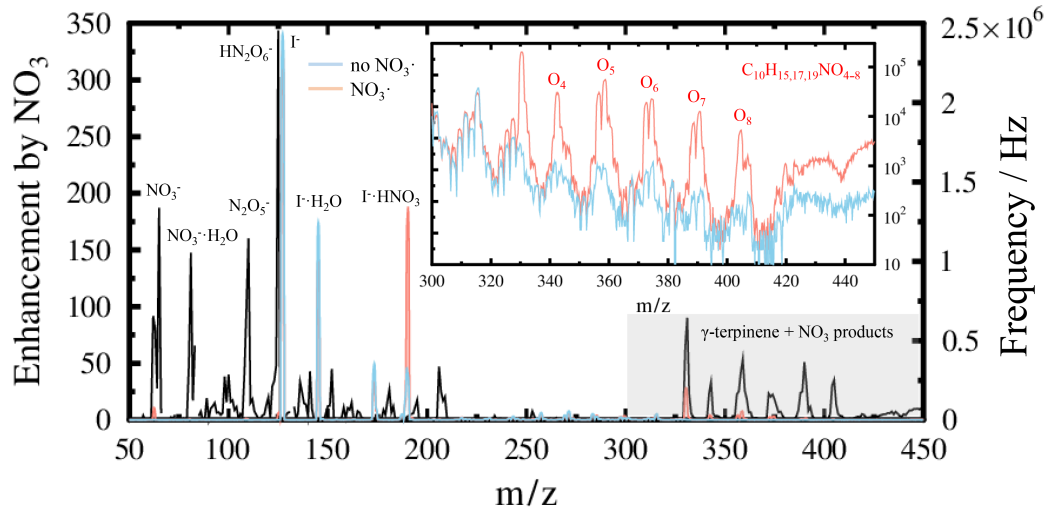

Figure 8. CIMS mass spectra before (blue) and after (red) $\gamma$-terpinene oxidation by $\mathrm{NO}_{3}$ correspond to right axis. Signal enhancement by addition of $\mathrm{NO}_{3}$ is shown in the black trace. The inset panel shows an enhanced region of the mass spectra corresponding to the shaded area, which indicates the presence of multifunctional ON compounds with the number of oxygen atoms consistent with the depicted chemical formula. The " $\mathrm{O}_{4}$ " peak was used to quantify hydroxy nitrate concentrations. Signal enhancement by addition of $\mathrm{NO}_{3}$ is shown in the black trace.

\subsection{CIMS product identification and hydroxy nitrate yields}

$\mathrm{NO}_{3}$ reactions with VOCs lead to either abstraction of a hydrogen atom or addition to a double bond. Since $\gamma$-terpinene has two double bonds of similar character, $\mathrm{NO}_{3}$ likely has equal probability of adding to either internal double bond. However, addition of $\mathrm{NO}_{3}$ to either one of the olefins is likely to form the more stable tertiary nitrooxy alkyl radical. Subsequent addition of $\mathrm{O}_{2}$ forms the $\beta$-nitrooxyperoxy radical that can lead to an array of products, including hydroxy nitrates, most likely from self or cross $\mathrm{RO}_{2}+\mathrm{RO}_{2}$ reactions or isomerization (Yeh and Ziemann, 2014; Ziemann and Atkinson, 2012). $\mathrm{C}_{10}$-derived hydroxy nitrates and other multifunctional ONs have been identified in field-sampled SOA particles, and for nighttime $\mathrm{ON}_{\mathrm{p}}, \mathrm{C}_{10}$-derived $\mathrm{ON}$ could account for approximately $10 \%$ of the organic aerosol mass during the Southern Oxidant and Aerosol Study (SOAS) campaign in the southeast US (Xu et al., 2015; Lee et al., 2016). However, our current understanding of $\mathrm{C}_{10}$-derived hydroxy nitrate yields is limited to production via oxidation of $\alpha$-pinene (Wangberg et al., 1997). Here we expand on this by determining the hydroxy nitrate yield from $\gamma$-terpinene oxidation by $\mathrm{NO}_{3}$ and identify other potentially important $\mathrm{ON}$ species using CIMS.

Figure 8 shows example CIMS mass spectra (red and blue traces) and the enhancements over the background in the presence of $\mathrm{NO}_{3}$ (black trace) following a chamber experiment, where the enhancement is calculated from the signal for $\frac{\mathrm{NO}_{3}-\mathrm{no} \mathrm{NO}_{3}}{\text { no } \mathrm{NO}_{3}}$. Several molecules were detected at masses below the iodide reagent ion signal $(m / z=127)$ following $\mathrm{N}_{2} \mathrm{O}_{5}$ addition to the chamber and correspond to $\mathrm{NO}_{3}^{-}(m / z=62), \mathrm{NO}_{3}^{-} \cdot\left(\mathrm{H}_{2} \mathrm{O}\right)_{1,2}(m / z=80,98), \mathrm{N}_{2} \mathrm{O}_{5}^{-}$ $(m / z=108)$, and what appears to be a nitrate-nitric acid cluster anion, $\mathrm{HN}_{2} \mathrm{O}_{6}^{-}(\mathrm{m} / z=125$; Dubowsky et al., 2015;
Huey, 2007). The water cluster ions and nitric acid (also at $m / z=190$, corresponding to $\mathrm{I}^{-} \cdot \mathrm{HNO}_{3}$ ) result from ionmolecule reactions in the humidified drift tube of our CIMS and residual $\mathrm{HNO}_{3}$ from the $\mathrm{N}_{2} \mathrm{O}_{5}$ cold trap. Several larger molecular weight species were detected in the range of $300 \leq$ $m / z \leq 450$, consistent with products from monoterpene oxidation, with enhancements over the background as large as a factor of 50 to 100 . Specifically, the first-generation hydroxy nitrates are observed at $m / z=342\left(\mathrm{C}_{10} \mathrm{H}_{17} \mathrm{NO}_{4}-\mathrm{I}^{-}\right)$. Several masses follow, separated by 16 mass units, or addition of a single oxygen atom, whereby each new ON has 15,17 , or $19 \mathrm{H}$ atoms. Similar observations were made in the field during the SOAS campaign for both $\mathrm{ON}_{\mathrm{g}}$ and $\mathrm{ON}_{\mathrm{p}}$ (Lee et al., 2016), indicating the presence of highly functionalized ONs. It is important to note that the products observed here are derived from a single monoterpene, whereas the field ON measurements consist of products derived from all ambient monoterpene oxidation. Other major peaks included those at $m / z=340$, potentially representing an iodide adduct with either an aldehyde or keto-nitrate $\left(\mathrm{C}_{10} \mathrm{H}_{15} \mathrm{NO}_{4}\right.$ $\mathrm{I}^{-}$), and $m / z=358$, which may be indicative of an iodide adduct with a hydroperoxy nitrate $\left(\mathrm{C}_{10} \mathrm{H}_{17} \mathrm{NO}_{5}-\mathrm{I}^{-}\right)$. A cluster of ions was detected above $m / z=400$, potentially representing molecules with higher degrees of oxygenation and secondary oxidation products such as a di-hydroxy dinitrate at $m / z=421\left(\mathrm{C}_{10} \mathrm{H}_{18} \mathrm{~N}_{2} \mathrm{O}_{8}-\mathrm{I}^{-}\right)$, which could be formed through second-generation oxidation at the remaining unsubstituted carbon of the double bond on the first-generation hydroxy nitrate. It is important to note that the CIMS sensitivity for each of these species is likely different and depends on the polarity and acidity of the individual compound, which is affected by the type and positions of the different functional groups (Lee et al., 2016). For example, iodide-adduct CIMS is not particularly sensitive to aldehyde and carbonyl nitrates, whereas more acidic and polar molecules such as hydroxy ni- 
trates and carboxylic acids can exhibit much greater sensitivity (Lee et al., 2016). Moreover, in general as the molecular size and number of oxygenated groups increase (particularly -OH groups), the sensitivity also increases. Hence, without commercial or custom synthetic standards, no quantitative analysis of the array of $\mathrm{ON}$ products could be reliably performed using this technique.

Here we determine the yield of $\gamma$-terpinene-derived hydroxy nitrates. Since there is no commercially available standard for the expected first-generation $\gamma$-terpinene hydroxy nitrate, we use a synthetic olefinic hydroxy nitrate derived from $\alpha$-pinene (structure shown in Fig. S4) for quantitative analysis (Rindelaub et al., 2016). It is possible that the CIMS is less sensitive to this nitrate compared to the more sensitive $\alpha, \beta$-hydroxy nitrate structure expected of the first-generation $\gamma$-terpinene hydroxy nitrates, similar to the differences in the CIMS sensitivity for 4,3-isoprene hydroxy nitrate (4,3IN) and 1,4-IN (Xiong et al., 2015). However, the use of an olefinic hydroxy nitrate is consistent with that expected from $\gamma$-terpinene oxidation because of its diolefinic character. As shown in Fig. 9, $\gamma$-terpinene-derived hydroxy nitrate concentrations increase linearly over the range of $\triangle \mathrm{BVOC}$ with a hydroxy nitrate yield defined from the slope as $4( \pm 1) \%$. Assuming the CIMS sensitivity for the $\gamma$-terpinene hydroxy nitrates may be a factor of 3 greater than for our synthetic $\alpha$-pinene-derived hydroxy nitrate, a more conservative estimate of the $\gamma$-terpinene-derived hydroxy nitrate yield is $4(+1 /-3) \%$. To our knowledge, the only monoterpene hydroxy nitrate yield to have been quantified following $\mathrm{NO}_{3}$ oxidation is 2-hydroxypinan-3-nitrate, derived from $\alpha$ pinene (Wangberg et al., 1997). In that study, the hydroxy nitrate yield was determined using a combination of FT-IR and GC-ECD to be $5( \pm 0.4) \%$, on the same order as the yield presented in this study for $\gamma$-terpinene using CIMS. 3-oxopinan2-nitrate $\left(\mathrm{C}_{10} \mathrm{H}_{15} \mathrm{NO}_{4} ; 213 \mathrm{~g} \mathrm{~mol}^{-1}\right)$ and a short-lived, thermally unstable peroxy nitrate $\left(\mathrm{C}_{10} \mathrm{H}_{16} \mathrm{~N}_{2} \mathrm{O}_{7} ; 276 \mathrm{~g} \mathrm{~mol}^{-1}\right)$ were also identified in that study. It is possible that similar products are made following $\mathrm{NO}_{3}$ oxidation of $\gamma$-terpinene, and potentially make up the signals detected at $\mathrm{m} / z=340$ and $m / z=403$, respectively, as shown in Fig. 8. However, the CIMS sensitivity toward these products is expected to be relatively small compared to that for the hydroxy nitrates, due to their relatively lower polarity and acidity. Moreover, peroxy nitrates are thermally unstable and their concentrations are likely greatly reduced during transfer through the heated sampling line.

\subsection{Proposed reaction mechanism}

The similarities among the, at first seemingly low, $\gamma$ terpinene $+\mathrm{NO}_{3}$-derived $Y_{\mathrm{ONt}}$, hydroxy nitrate yield, and $Y_{\text {SOA }}$ with those for $\mathrm{NO}_{3}+\alpha$-pinene are provocative. This suggests the two monoterpenes may undergo very similar degradation pathways following $\mathrm{NO}_{3}$ oxidation, which is not observed with other monoterpenes with a substituted endo-

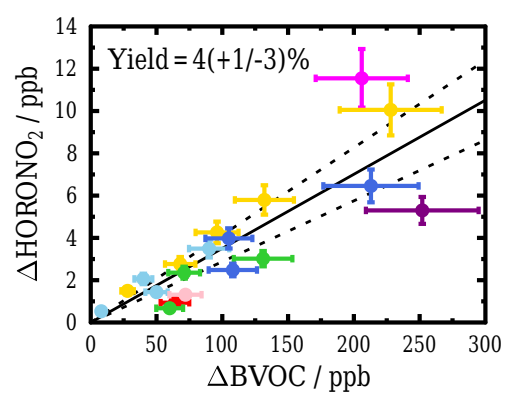

Figure 9. $\gamma$-terpinene hydroxy nitrate production $\left(\triangle \mathrm{HORONO}_{2}\right)$ as a function of the amount of BVOC consumed ( $\triangle \mathrm{BVOC})$. Colors represent independent experiments performed on different days. All of the experiments were conducted in the absence of seed aerosol. The error bars and fits are derived as in Fig. 3.

cyclic double bond (Fry et al., 2014). As such, our mechanistic interpretation, shown in Fig. 5, is analogous to that for the $\alpha$-pinene $+\mathrm{NO}_{3}$ reaction, as described in the Master Chemical Mechanism (MCM; Jenkin et al., 1997; Saunders et al., 2003). $\mathrm{NO}_{3}$ will predominately add to the $\mathrm{C}_{3}$ (unsubstituted) position forming the more stable tertiary alkyl radical. However, to some extent, $\mathrm{NO}_{3}$ may also add to the second carbon forming the less stable secondary alkyl radical, approximately $35 \%$ of the time according to the MCM. Oxygen promptly adds to the alkyl radical to form either a tertiary or secondary peroxy radical $\left(\mathrm{RO}_{2} \bullet\right)$. Excess $\mathrm{NO}_{2}$, due to thermal decomposition of $\mathrm{N}_{2} \mathrm{O}_{5}$, can add to the peroxy radical forming a thermally unstable peroxy nitrate $\left(-\mathrm{OONO}_{2}\right)$ in equilibrium with the peroxy radical. Subsequent $\mathrm{RO}_{2}$ - self- and cross-reactions as well as reaction with $\mathrm{NO}_{3}$ form the alkoxy radical (RO•). The alkoxy radical can subsequently decompose to form a carbonyl nitrate or $\gamma$-terpinaldehyde (Fig. 5) and release $\mathrm{NO}_{2}$. Analogously, pinonaldehyde is the major $\mathrm{NO}_{3}$ oxidation product of $\alpha$-pinene with reported yields of $62( \pm 4) \%$ (Wangberg et al., 1997) and 75( \pm 6$) \%$ (Berndt and Böge, 1997). Given the very similar tertiary alkoxy radicals produced from $\mathrm{NO}_{3}$ oxidation of $\alpha$-pinene and $\gamma$-terpinene, and the similar SOA, $\mathrm{ON}_{t}$, and hydroxy nitrate yields, conceivably $\gamma$ terpinaldehyde is produced and with similarly high but undetermined yields as pinonaldehyde from $\alpha$-pinene oxidation by $\mathrm{NO}_{3}$. Similar results have been reported for the ozonolysis of $\gamma$-terpinene, which primarily leads to decomposition and formation of $\gamma$-terpinaldehyde with a yield of $58 \%(\mathrm{Ng}$ et al., 2006). Alternatively, disproportionation, involving a secondary peroxy radical, produces a hydroxy nitrate and a carbonyl compound from the partnering $\mathrm{RO}_{2}$ (Yeh and Ziemann, 2014; Ziemann and Atkinson, 2012; Wangberg et al., 1997). As we have shown, the experimentally derived yield for these products is $4 \%$, or roughly $25 \%$ of $\mathrm{ON}_{\mathrm{t}}$. The remaining organic nitrate species likely contains both carbonyl and hydroperoxy $(-\mathrm{OOH})$ functionalities, and perhaps peroxy nitrates, following $\mathrm{NO}_{2}$ addition to the peroxy radical. 
A major species detected by our CIMS has an $m / z=358$, which may represent an $\mathrm{I}^{-}$adduct with a hydroperoxy nitrate. This product is only produced due to reactions between hydroperoxy radicals $\left(\mathrm{HO}_{2} \cdot\right.$ ) and $\mathrm{RO}_{2} \cdot$ (Ziemann and Atkinson, 2012). Conceivably, $\mathrm{HO}_{2}$ - is produced in our system from hydrogen abstraction from alkoxy radicals by oxygen (Wangberg et al., 1997).

To test the hypothesis that $\gamma$-terpinene behaves similarly to $\alpha$-pinene following reaction with $\mathrm{NO}_{3}$, we ran a simple box model based on the mechanisms for $\mathrm{NO}_{3}$ oxidation of $\alpha$-pinene as presented in the MCM, and compared the model output with the measured concentrations of $\gamma$ terpinene, $\mathrm{NO}_{2}$, and hydroxy nitrates. The model is constrained by the initial and final GC-FID-derived concentrations of $\gamma$-terpinene. Since the nitrate radical concentration was not determined experimentally, the concentration of $\mathrm{NO}_{3}$ in the model was determined by adjusting the $\mathrm{N}_{2} \mathrm{O}_{5}$ concentration until the fitted concentration change of $\gamma$ terpinene matched that which was measured. This approach implicitly assumes $\gamma$-terpinene is consumed only from reaction with $\mathrm{NO}_{3}$, which is expected given the orders-ofmagnitude greater reactivity of $\mathrm{NO}_{3}$ compared to the other reactants in our system, which includes $\mathrm{N}_{2} \mathrm{O}_{5}$ and $\mathrm{NO}_{2}$. The results of the model are presented in Fig. 10. For comparison, modeled concentrations are plotted along with the measured concentrations of $\gamma$-terpinene, $\mathrm{NO}_{2}$, and hydroxy nitrates derived from one of the experiments. At first approximation, the modeled concentrations appear to be in agreement with those measured, given the semi-quantitative nature of the product, particularly the hydroperoxides. As shown in the top panel of Fig. $10, \mathrm{NO}_{3} / \mathrm{HO}_{2}$ ratios are $\sim 3$ at peak $\left[\mathrm{HO}_{2}\right]$, then decrease to $\sim 1$ as the products reach steady state. In comparison, ambient nighttime $\mathrm{NO}_{3} / \mathrm{HO}_{2}$ ratios of $\sim 1$ have been measured during the PROPHET 1998 field intensive in northern Michigan (Hurst et al., 2001; Tan et al., 2001), and $\sim 0.25$ at the BEARPEX field site in north central California (Bouvier-Brown et al., 2009; Mao et al., 2012). The relatively larger ratios in our chamber, initially, suggest hydroperoxy nitrates may be underrepresented compared to the atmosphere. Notably, the agreement between modeled and measured $\left[\mathrm{NO}_{2}\right]$ implies that model-derived $\left[\mathrm{N}_{2} \mathrm{O}_{5}\right]$ is close to that in the reaction chamber as $\left[\mathrm{NO}_{2}\right]$ is in equilibrium with $\mathrm{N}_{2} \mathrm{O}_{5}$. Although not quantified experimentally, qualitative analysis of the CIMS mass spectra indicates the presence of carbonyl and hydroperoxy nitrates, which is consistent with the major ON products expected from the mechanism shown in Fig. 5.

\section{Atmospheric implications}

The relatively low SOA and ON yields observed here under dry conditions at ambient mass loadings suggests $\gamma$ terpinene may not be an important SOA precursor at night, when $\mathrm{NO}_{3}$ can be the dominant oxidant. However, the low

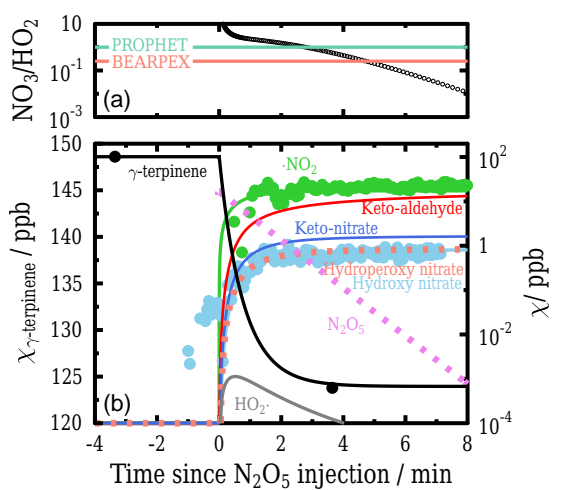

Figure 10. Modeled and measured time series of experiment. Panel (a) shows simulated $\mathrm{NO}_{3} / \mathrm{HO}_{2}$ ratios (black circles) compared to measured ambient nighttime ratios from the PROPHET and BEARPEX field intensives. Panel (b) shows modeled (lines) and measured (circles) concentrations of $\gamma$-terpinene (black), $\mathrm{N}_{2} \mathrm{O}_{5}$ (dashed violet), $\mathrm{NO}_{2}$ (green), $\mathrm{HO}_{2}$ (gray), keto-aldehyde (red), keto-nitrate (dark blue), hydroperoxy nitrate (dashed pink), and hydroxy nitrate (light blue). The model is based on the MCM for $\alpha$ pinene reaction with $\mathrm{NO}_{3}$.

saturation vapor pressure of the hydroxy nitrates, which constitute a significant portion of the total $\mathrm{ON}$, and the presence of some highly oxygenated products, further suggests that these molecules are potentially important contributors to SOA mass. While our experiments were conducted near dry conditions, in the ambient forest environment, particularly at night and in the early morning when the relative humidity near the surface is high and $\mathrm{NO}_{3}$ reactions are competitive with $\mathrm{O}_{3}$ and $\mathrm{OH}$, hydroxy nitrates in the particle phase can enhance SOA formation through acid-catalyzed hydrolysis and oligomerization, and in the presence of sulfates, form organic sulfates (Liu et al., 2012; Paulot et al., 2009; Rindelaub et al., 2016; Surratt et al., 2008; Rindelaub et al., 2015), ultimately affecting the lifetime of $\mathrm{NO}_{x}$ (Browne and Cohen, 2012; Xiong et al., 2015). Furthermore, the transformation of the nitrooxy group to a hydroxyl or sulfate group will alter the hygroscopicity of the particle, making them more effective cloud condensation nuclei (Suda et al., 2014).

It is important to note that under relatively clean air conditions, the peroxy radical produced via $\mathrm{NO}_{3}$ reaction with $\gamma$ terpinene will often react with $\mathrm{HO}_{2}$ to produce nitrooxy hydroperoxides. As shown in the reaction scheme (b) in Fig. 7, these species can then react with $\mathrm{NO}_{3}$ and then $\mathrm{HO}_{2}, \mathrm{RO}_{2}$ or $\mathrm{NO}_{3}$ again, to yield a variety of highly oxidized very low vapor pressure products that will likely partition completely to the aerosol phase. Under humid conditions, the nitrooxy groups may hydrolyze, leaving more polar/water-soluble $\mathrm{OH}$ groups.

Although the SOA yields are low, these chamber experiments did not represent all possible reactants that can produce particle-phase precursors. Recent work indicates ketoaldehydes are potentially an important source of nitrogen- 
containing low-volatility compounds following their reaction with dimethylamine, serving as precursors to SOA and brown carbon (Duporté et al., 2016). As shown in this study, the keto-aldehyde yield is expected to be large, along with other internal olefinic terpenes. It is also important to note that the keto-aldehyde product, $\gamma$-terpinaldehyde, is olefinic. Further homogeneous and multiphase oxidation reactions at the remaining reactive double bond can potentially transform these species into oligomeric lower-volatility oxidation products, adding to the overall SOA burden (Liggio and $\mathrm{Li}$, 2008). In regions such as the northern US, where there are greater proportions of polyolefinic monoterpenes (Geron et al., 2000), $\gamma$-terpinene may be an important reactive VOC, and thus impact aerosol and local-scale $\mathrm{NO}_{x}$.

\section{Conclusions}

The total molar ON yield from the $\mathrm{NO}_{3}$ oxidation of $\gamma$ terpinene was found to be $14(+3 /-2) \%$. Relatively low particle-phase ON and SOA yields are consistent with previous studies that show SOA yields are generally dependent on the yield of ON. Although $\gamma$-terpinene is a diolefin, the ON, hydroxy nitrate, and SOA yields are similar to those for $\alpha$-pinene oxidation by $\mathrm{NO}_{3}$. Considering the position of the two double bonds, the expected major product is $\gamma$ terpinaldehyde, which is considerably more volatile than the ON products. Box model calculations that assume large ketoaldehyde yields are also in agreement with the measured concentrations of hydroxy nitrates, suggesting very similar mechanistic behavior to that of $\alpha$-pinene oxidation. Several gas- and particle-phase ON products have been inferred from mass spectrometry analysis, indicating that $\mathrm{NO}_{3}$ reaction with $\gamma$-terpinene may be an important source of $\mathrm{ON}$ and dicarbonyl compounds in forest-impacted environments.

Data availability. MATLAB model code and datasets for figures presented in the manuscript are now available for public access under the Purdue University Research Repository, https://doi.org/10.4231/R7CZ35BD (Slade, 2017).

\section{The Supplement related to this article is available online at https://doi.org/10.5194/acp-17-8635-2017-supplement.}

Author contributions. JHS and PBS designed the research and wrote the manuscript. JHS performed the yield experiments and analyzed the data. JHS and CdP analyzed the filter samples. LL oversaw the analysis of the filter samples. All authors contributed intellectually to the manuscript.
Competing interests. The authors declare that they have no conflict of interest.

Acknowledgements. Jonathan H. Slade and Paul B. Shepson acknowledge support from the National Science Foundation grant CHE-1550398.

Edited by: Alexander Laskin

Reviewed by: three anonymous referees

\section{References}

Abbatt, J. P. D., Lee, A. K. Y., and Thornton, J. A.: Quantifying trace gas uptake to tropospheric aerosol: recent advances and remaining challenges, Chem. Soc. Rev., 41, 6555-6581, https://doi.org/10.1039/C2cs35052a, 2012.

Atkinson, R., Aschmann, S. M., Carter, W. P. L., Winer, A. M., and Pitts, J. N.: Alkyl Nitrate Formation from the Nox-Air Photooxidations of C2-C8 N-Alkanes, J. Phys. Chem., 86, 4563-4569, https://doi.org/10.1021/j100220a022, 1982.

Ayres, B. R., Allen, H. M., Draper, D. C., Brown, S. S., Wild, R. J., Jimenez, J. L., Day, D. A., Campuzano-Jost, P., Hu, W., de Gouw, J., Koss, A., Cohen, R. C., Duffey, K. C., Romer, P., Baumann, K., Edgerton, E., Takahama, S., Thornton, J. A., Lee, B. H., Lopez-Hilfiker, F. D., Mohr, C., Wennberg, P. O., Nguyen, T. B., Teng, A., Goldstein, A. H., Olson, K., and Fry, J. L.: Organic nitrate aerosol formation via $\mathrm{NO}_{3}$ + biogenic volatile organic compounds in the southeastern United States, Atmos. Chem. Phys., 15, 13377-13392, https://doi.org/10.5194/acp-1513377-2015, 2015.

Beaver, M. R., Clair, J. M. St., Paulot, F., Spencer, K. M., Crounse, J. D., LaFranchi, B. W., Min, K. E., Pusede, S. E., Wooldridge, P. J., Schade, G. W., Park, C., Cohen, R. C., and Wennberg, P. O.: Importance of biogenic precursors to the budget of organic nitrates: observations of multifunctional organic nitrates by CIMS and TD-LIF during BEARPEX 2009, Atmos. Chem. Phys., 12, 5773-5785, https://doi.org/10.5194/acp-12-5773-2012, 2012.

Berkemeier, T., Ammann, M., Mentel, T. F., Pöschl, U., and Shiraiwa, M.: Organic nitrate contribution to new particle formation and growth in secondary organic aerosols from alphapinene ozonolysis, Environ. Sci. Technol., 50, 6334-6342, https://doi.org/10.1021/acs.est.6b00961, 2016.

Berndt, T. and Böge, O.: Products and mechanisms of the gas-phase reaction of $\mathrm{NO}_{3}$ radicals with $\alpha$-pinene, J. Chem. Soc. Fraday Trans., 93, 3021-3027, https://doi.org/10.1039/a702364b, 1997.

Bindu, G., Nair, P. R., Aryasree, S., Hegde, P., and Jacob, S.: Pattern of aerosol mass loading and chemical composition over the atmospheric environment of an urban coastal station, J. Atmos. Sol.-Terr. Phy., 138-139, 121-135, https://doi.org/10.1016/j.jastp.2016.01.004, 2016.

Bouvier-Brown, N. C., Goldstein, A. H., Gilman, J. B., Kuster, W. C., and de Gouw, J. A.: In-situ ambient quantification of monoterpenes, sesquiterpenes, and related oxygenated compounds during BEARPEX 2007: implications for gas- and particle-phase chemistry, Atmos. Chem. Phys., 9, 5505-5518, https://doi.org/10.5194/acp-9-5505-2009, 2009 
Boyd, C. M., Sanchez, J., Xu, L., Eugene, A. J., Nah, T., Tuet, W. Y., Guzman, M. I., and Ng, N. L.: Secondary organic aerosol formation from the $\beta$-pinene $+\mathrm{NO}_{3}$ system: effect of humidity and peroxy radical fate, Atmos. Chem. Phys., 15, 7497-7522, https://doi.org/10.5194/acp-15-7497-2015, 2015.

Browne, E. C. and Cohen, R. C.: Effects of biogenic nitrate chemistry on the $\mathrm{NO}_{x}$ lifetime in remote continental regions, Atmos. Chem. Phys., 12, 11917-11932, https://doi.org/10.5194/acp-1211917-2012, 2012.

Capouet, M., Müller, J.-F., Ceulemans, K., Compernolle, S., and Vereecken, L.: Modeling aerosol formation in alpha-pinene photo-oxidation experiments, J. Geophys. Res., 113, D02308, https://doi.org/10.1029/2007JD008995, 2008.

Carlton, A. G. and Turpin, B. J.: Particle partitioning potential of organic compounds is highest in the Eastern US and driven by anthropogenic water, Atmos. Chem. Phys., 13, 10203-10214, https://doi.org/10.5194/acp-13-10203-2013, 2013.

Chen, X., Hulbert, D., and Shepson, P. B.: Measurement of the organic nitrate yield from $\mathrm{OH}$ reaction with isoprene, J. Geophys. Res., 103, 25563-25568, https://doi.org/10.1029/98JD01483, 1998.

Compernolle, S., Ceulemans, K., and Müller, J.-F.: EVAPORATION: a new vapour pressure estimation methodfor organic molecules including non-additivity and intramolecular interactions, Atmos. Chem. Phys., 11, 9431-9450, https://doi.org/10.5194/acp-11-9431-2011, 2011.

Darer, A. I., Cole-Filipiak, N. C., O'Connor, A. E., and Elrod, M. J.: Formation and stability of atmospherically relevant isoprenederived organosulfates and organonitrates, Environ. Sci. Technol., 45, 1895-1902, https://doi.org/10.1021/es103797z, 2011.

Darnall, K. R. and Pitts, J. N.: Peroxyacetyl Nitrate - a Novel Reagent for Oxidation of Organic Compounds, J. Chem. Soc. Chem. Comm., 1305-1306, https://doi.org/10.1039/c29700001305, 1970.

Darnall, K. R., Carter, W. P. L., Winer, A. M., Lloyd, A. C., and Pitts, J. N.: Importance of $\mathrm{RO}_{2}+\mathrm{NO}$ in alkyl nitrate formation from C4-C6 alkane photooxidations under simulated atmospheric conditions, J. Phys. Chem., 80, 1948-1950, https://doi.org/10.1021/j100558a029, 1976.

Docherty, K. S., Wu, W., Lim, Y. B., and Ziemann, P. J.: Contributions of organic peroxides to secondary aerosol formed from reactions of monoterpenes with O-3, Environ. Sci. Technol., 39, 4049-4059, https://doi.org/10.1021/es050228s, 2005.

Donahue, N. M., Epstein, S. A., Pandis, S. N., and Robinson, A. L.: A two-dimensional volatility basis set: 1. organic-aerosol mixing thermodynamics, Atmos. Chem. Phys., 11, 3303-3318, https://doi.org/10.5194/acp-11-3303-2011, 2011.

Dubowsky, S. E., Friday, D. M., Peters, K. C., Zhao, Z. J., Perry, R. H., and McCall, B. J.: Mass spectrometry of atmosphericpressure ball plasmoids, Int. J. Mass Spectrom., 376, 39-45, https://doi.org/10.1016/j.ijms.2014.11.011, 2015.

Duporté, G., Parshintsev, J., Barreira, L. M. F., Hartonen, K., Kulmala, M., and Riekkola, M. L.: Nitrogen-containing low volatile compounds from pinonaldehyde-dimethylamine reaction in the atmosphere: a laboratory and field study, Environ. Sci. Technol., 50, 4693-4700, https://doi.org/10.1021/acs.est.6b00270, 2016.

Fry, J. L., Kiendler-Scharr, A., Rollins, A. W., Wooldridge, P. J., Brown, S. S., Fuchs, H., Dubé, W., Mensah, A., dal Maso, M., Tillmann, R., Dorn, H.-P., Brauers, T., and Cohen, R.
C.: Organic nitrate and secondary organic aerosol yield from $\mathrm{NO}_{3}$ oxidation of $\beta$-pinene evaluated using a gas-phase kinetics/aerosol partitioning model, Atmos. Chem. Phys., 9, 14311449, https://doi.org/10.5194/acp-9-1431-2009, 2009.

Fry, J. L., Draper, D. C., Zarzana, K. J., Campuzano-Jost, P., Day, D. A., Jimenez, J. L., Brown, S. S., Cohen, R. C., Kaser, L., Hansel, A., Cappellin, L., Karl, T., Hodzic Roux, A., Turnipseed, A., Cantrell, C., Lefer, B. L., and Grossberg, N.: Observations of gas- and aerosol-phase organic nitrates at BEACHON-RoMBAS 2011, Atmos. Chem. Phys., 13, 85858605, https://doi.org/10.5194/acp-13-8585-2013, 2013.

Fry, J. L., Draper, D. C., Barsanti, K. C., Smith, J. N., Ortega, J., Winkler, P. M., Lawler, M. J., Brown, S. S., Edwards, P. M., Cohen, R. C., and Lee, L.: Secondary organic aerosol formation and organic nitrate yield from $\mathrm{NO}_{3}$ oxidation of biogenic hydrocarbons, Environ. Sci. Technol., 48, 11944-11953, https://doi.org/10.1021/es502204x, 2014.

Geron, C., Rasmussen, R., Arnts, R., and Guenther, A. B.: A review and synthesis of monoterpene speciation from forests in the United States, Atmos. Environ., 34, 1761-1781, https://doi.org/10.1016/S1352-2310(99)00364-7, 2000.

Glasius, M. and Goldstein, A. H.: Recent discoveries and future challenges in atmospheric organic chemistry, Environ. Sci. Technol., 50, 2754-2764, https://doi.org/10.1021/acs.est.5b05105, 2016.

Goldstein, A. H. and Galbally, I. E.: Known and unexplored organic constituents in the Earth's atmosphere, Environ. Sci. Technol., 41, 1514-1521, https://doi.org/10.1021/es072476p, 2007.

Griffin, R. J., Cocker III, D. R., Flagan, R. C., and Seinfeld, J. H.: Organic aerosol formation from the oxidation of biogenic hydrocarbons, J. Geophys. Res., 104, 3555-3567, https://doi.org/10.1029/1998JD100049, 1999.

Grossenbacher, J. W., Barket, D. J., Shepson, P. B., Carroll, M. A., Olszyna, K., and Apel, E.: A comparison of isoprene nitrate concentrations at two forest-impacted sites, J. Geophys. Res.Atmos., 109, https://doi.org/10.1029/2003jd003966, 2004.

Guenther, A.: The contribution of reactive carbon emissions from vegetation to the carbon balance of terrestrial ecosystems, Chemosphere, 49, 837-844, https://doi.org/10.1016/S00456535(02)00384-3, 2002.

Guenther, A., Hewitt, C. N., Erickson, D., Fall, R., Geron, C., Graedel, T., Harley, P., Klinger, L., Lerdau, M., Mckay, W. A., Pierce, T., Scholes, B., Steinbrecher, R., Tallamraju, R., Taylor, J., and Zimmerman, P.: A global model of natural volatile organic compound emissions, J. Geophys. Res., 100, 8873-8892, https://doi.org/10.1029/94JD02950, 1995.

Hallquist, M., Wenger, J. C., Baltensperger, U., Rudich, Y., Simpson, D., Claeys, M., Dommen, J., Donahue, N. M., George, C., Goldstein, A. H., Hamilton, J. F., Herrmann, H., Hoffmann, T., Iinuma, Y., Jang, M., Jenkin, M. E., Jimenez, J. L., Kiendler-Scharr, A., Maenhaut, W., McFiggans, G., Mentel, Th. F., Monod, A., Prévôt, A. S. H., Seinfeld, J. H., Surratt, J. D., Szmigielski, R., and Wildt, J.: The formation, properties and impact of secondary organic aerosol: current and emerging issues, Atmos. Chem. Phys., 9, 5155-5236, https://doi.org/10.5194/acp9-5155-2009, 2009.

Hao, L. Q., Romakkaniemi, S., Yli-Pirilä, P., Joutsensaari, J., Kortelainen, A., Kroll, J. H., Miettinen, P., Vaattovaara, P., Tiitta, P., Jaatinen, A., Kajos, M. K., Holopainen, J. K., Heijari, J., Rinne, 
J., Kulmala, M., Worsnop, D. R., Smith, J. N., and Laaksonen, A.: Mass yields of secondary organic aerosols from the oxidation of $\alpha$-pinene and real plant emissions, Atmos. Chem. Phys., 11, 1367-1378, https://doi.org/10.5194/acp-11-1367-2011, 2011.

Hoyle, C. R., Boy, M., Donahue, N. M., Fry, J. L., Glasius, M., Guenther, A., Hallar, A. G., Huff Hartz, K., Petters, M. D., Petäjä, T., Rosenoern, T., and Sullivan, A. P.: A review of the anthropogenic influence on biogenic secondary organic aerosol, Atmos. Chem. Phys., 11, 321-343, https://doi.org/10.5194/acp-11-3212011, 2011.

Huey, L. G.: Measurement of trace atmospheric species by chemical ionization mass spectrometry: Speciation of reactive nitrogen and future directions, Mass Spectrom. Rev., 26, 166-184, https://doi.org/10.1002/mas.20118, 2007.

Hurst, J. M., Barket, D. J., Herrera-Gomez, O., Couch, T. L., Shepson, P. B., Faloona, I., Tan, D., Brune, W., Westberg, H., Lamb, B., Biesenthal, T., Young, V., Goldstein, A., Munger, J. W., Thornberry, T., and Carroll, M. A.: Investigation of the nighttime decay of isoprene, J. Geophys. Res.-Atmos., 106, 24335-24346, https://doi.org/10.1029/2000jd900727, 2001.

Jacobs, M. I., Burke, W. J., and Elrod, M. J.: Kinetics of the reactions of isoprene-derived hydroxynitrates: gas phase epoxide formation and solution phase hydrolysis, Atmos. Chem. Phys., 14, 8933-8946, https://doi.org/10.5194/acp-14-8933-2014, 2014.

Jenkin, M. E., Saunders, S. M., and Pilling, M. J.: The tropospheric degradation of volatile organic compounds: A protocol for mechanism development, Atmos. Environ., 31, 81-104, https://doi.org/10.1016/S1352-2310(96)00105-7, 1997.

Kokkola, H., Yli-Pirilä, P., Vesterinen, M., Korhonen, H., Keskinen, H., Romakkaniemi, S., Hao, L., Kortelainen, A., Joutsensaari, J., Worsnop, D. R., Virtanen, A., and Lehtinen, K. E. J.: The role of low volatile organics on secondary organic aerosol formation, Atmos. Chem. Phys., 14, 1689-1700, https://doi.org/10.5194/acp-14-1689-2014, 2014.

Kroll, J. H. and Seinfeld, J. H.: Chemistry of secondary organic aerosol: formation and evolution of low-volatility organics in the atmosphere, Atmos. Environ., 42, 3593-3624, https://doi.org/10.1016/j.atmosenv.2008.01.003, 2008.

Lee, A., Goldstein, A. H., Kroll, J. H., Ng, N. L., Varutbangkul, V., Flagan, R. C., and Seinfeld, J. H.: Gas-phase products and secondary aerosol yields from the photooxidation of 16 different terpenes, J. Geophys. Res., 111, D17305, https://doi.org/10.1029/2006JD007050, 2006.

Lee, B. H., Mohr, C., Lopez-Hilfiker, F. D., Lutz, A., Hallquist, M., Lee, L., Romer, P., Cohen, R. C., Lyer, S., Kurten, T., Hu, W., Day, D. A., Campuzano-Jost, P., Jimenez, J. L., Xu, L., Ng, N. L., Guo, H., Weber, R. J., Wilde, R. J., Brown, S. S., Koss, A., de Gouw, J., Olson, K., Goldstein, A. H., Seco, R., Kim, S., McAvey, K. M., Shepson, P. B., Starn, T. K., Baumann, K., Edgerton, E. S., Liu, J., Shilling, J. E., Miller, D. O., Brune, W., Schobesberger, S., D'Ambro, E. L., and Thornton, J. A.: Highly functionalized organic nitrates in the southeast United States: contribution to secondary organic aerosol and reactive nitrogen budgets, P. Natl. Acad. Sci. USA, 113, 1516-1521, https://doi.org/10.1073/pnas.1508108113, 2016.

Liggio, J. and Li, S.-M.: Reversible and irreversible processing of biogenic olefins on acidic aerosols, Atmos. Chem. Phys., 8, 2039-2055, https://doi.org/10.5194/acp-8-2039-2008, 2008.
Liu, S., Shilling, J. E., Song, C., Hiranuma, N., Zaveri, R. A., and Russell, L. M.: Hydrolysis of organonitrate functional groups in aerosol particles, Aerosol Sci. Tech., 46, 1359-1369, https://doi.org/10.1080/02786826.2012.716175, 2012.

Lockwood, A. L., Shepson, P. B., Fiddler, M. N., and Alaghmand, M.: Isoprene nitrates: preparation, separation, identification, yields, and atmospheric chemistry, Atmos. Chem. Phys., 10, 6169-6178, https://doi.org/10.5194/acp-10-6169-2010, 2010.

Mao, J., Ren, X., Zhang, L., Van Duin, D. M., Cohen, R. C., Park, J.-H., Goldstein, A. H., Paulot, F., Beaver, M. R., Crounse, J. D., Wennberg, P. O., DiGangi, J. P., Henry, S. B., Keutsch, F. N., Park, C., Schade, G. W., Wolfe, G. M., Thornton, J. A., and Brune, W. H.: Insights into hydroxyl measurements and atmospheric oxidation in a California forest, Atmos. Chem. Phys., 12, 8009-8020, https://doi.org/10.5194/acp-12-8009-2012, 2012.

Nah, T., McVay, R. C., Zhang, X., Boyd, C. M., Seinfeld, J. H., and $\mathrm{Ng}, \mathrm{N}$. L.: Influence of seed aerosol surface area and oxidation rate on vapor wall deposition and SOA mass yields: a case study with a-pinene ozonolysis, Atmos. Chem. Phys., 16, 9361-9379, https://doi.org/10.5194/acp-16-9361-2016, 2016.

Ng, N. L., Kroll, J. H., Keywood, M. D., Bahreini, R., Varutbangkul, V., Flagan, R. C., Seinfeld, J. H., Lee, A., and Goldstein, A. H.: Contribution of first- versus second-generation products to secondary organic aerosols formed in the oxidation of biogenic hydrocarbons, Environ. Sci. Technol., 40, 2283-2297, https://doi.org/10.1021/es052269u, 2006.

Ng, N. L., Chhabra, P. S., Chan, A. W. H., Surratt, J. D., Kroll, J. H., Kwan, A. J., McCabe, D. C., Wennberg, P. O., Sorooshian, A., Murphy, S. M., Dalleska, N. F., Flagan, R. C., and Seinfeld, J. H.: Effect of $\mathrm{NO}_{x}$ level on secondary organic aerosol (SOA) formation from the photooxidation of terpenes, Atmos. Chem. Phys., 7, 5159-5174, https://doi.org/10.5194/acp-7-5159-2007, 2007.

Ng, N. L., Brown, S. S., Archibald, A. T., Atlas, E., Cohen, R. C., Crowley, J. N., Day, D. A., Donahue, N. M., Fry, J. L., Fuchs, H., Griffin, R. J., Guzman, M. I., Herrmann, H., Hodzic, A., Iinuma, Y., Jimenez, J. L., Kiendler-Scharr, A., Lee, B. H., Luecken, D. J., Mao, J., McLaren, R., Mutzel, A., Osthoff, H. D., Ouyang, B., Picquet-Varrault, B., Platt, U., Pye, H. O. T., Rudich, Y., Schwantes, R. H., Shiraiwa, M., Stutz, J., Thornton, J. A., Tilgner, A., Williams, B. J., and Zaveri, R. A.: Nitrate radicals and biogenic volatile organic compounds: oxidation, mechanisms, and organic aerosol, Atmos. Chem. Phys., 17, 2103-2162, https://doi.org/10.5194/acp-17-2103-2017, 2017.

Nguyen, T. B., Crounse, J. D., Schwantes, R. H., Teng, A. P., Bates, K. H., Zhang, X., St. Clair, J. M., Brune, W. H., Tyndall, G. S., Keutsch, F. N., Seinfeld, J. H., and Wennberg, P. O.: Overview of the Focused Isoprene eXperiment at the California Institute of Technology (FIXCIT): mechanistic chamber studies on the oxidation of biogenic compounds, Atmos. Chem. Phys., 14, 1353113549, https://doi.org/10.5194/acp-14-13531-2014, 2014.

Odum, J. R., Hoffmann, T., Bowman, F., Collins, D., Flagan, R. C., and Seinfeld, J. H.: Gas/particle partitioning and secondary organic aerosol yields, Environ. Sci. Technol., 30, 2580-2585, https://doi.org/10.1021/es950943+, 1996.

Pankow, J. F. and Asher, W. E.: SIMPOL.1: a simple group contribution method for predicting vapor pressures and enthalpies of vaporization of multifunctional organic compounds, Atmos. Chem. Phys., 8, 2773-2796, https://doi.org/10.5194/acp-8-27732008, 2008. 
Paulot, F., Crounse, J. D., Kjaergaard, H. G., Kroll, J. H., Seinfeld, J. H., and Wennberg, P. O.: Isoprene photooxidation: new insights into the production of acids and organic nitrates, Atmos. Chem. Phys., 9, 1479-1501, https://doi.org/10.5194/acp-9-14792009, 2009.

Pratt, K. A., Mielke, L. H., Shepson, P. B., Bryan, A. M., Steiner, A. L., Ortega, J., Daly, R., Helmig, D., Vogel, C. S., Griffith, S., Dusanter, S., Stevens, P. S., and Alaghmand, M.: Contributions of individual reactive biogenic volatile organic compounds to organic nitrates above a mixed forest, Atmos. Chem. Phys., 12, 10125-10143, https://doi.org/10.5194/acp-12-101252012, 2012.

Presto, A. A., Hartz, K. E. H., and Donahue, N. M.: Secondary organic aerosol production from terpene ozonolysis. 2. Effect of $\mathrm{NO}_{x}$ concentration, Environ. Sci. Technol., 39, 7046-7054, https://doi.org/10.1021/es050400s, 2005.

Pye, H. O. T., Luecken, D. J., Xu, L., Boyd, C. M., Ng, N. L., Baker, K. R., Ayres, B. R., Bash, J. O., Baumann, K., Carter, W. P. L., Edgerton, E. S., Fry, J. L., Hutzell, W. T., Schwede, D. B., and Shepson, P. B.: Modeling the current and future roles of particulate organic nitrates in the Southeastern United States, Environ. Sci. Technol., 49, 14195-14203, https://doi.org/10.1021/acs.est.5b03738, 2015.

Reinnig, M. C., Warnke, J., and Hoffmann, T.: Identification of organic hydroperoxides and hydroperoxy acids in secondary organic aerosol formed during the ozonolysis of different monoterpenes and sesquiterpenes by on-line analysis using atmospheric pressure chemical ionization ion trap mass spectrometry, Rapid Commun. Mass Sp., 23, 1735-1741, https://doi.org/10.1002/rcm.4065, 2009.

Riipinen, I., Yli-Juuti, T., Pierce, J. R., Petaja, T., Worsnop, D. R., Kulmala, M., and Donahue, N. M.: The contribution of organics to atmospheric nanoparticle growth, Nat. Geosci., 5, 453-458, https://doi.org/10.1038/ngeo1499, 2012.

Rindelaub, J. D., McAvey, K. M., and Shepson, P. B.: The photochemical production of organic nitrates from alpha-pinene and loss via acid-dependent particle phase hydrolysis, Atmos. Environ., 100, 193-201, https://doi.org/10.1016/j.atmosenv.2014.10.010, 2015.

Rindelaub, J. D., Borca, C. H., Hostetler, M. A., Slade, J. H., Lipton, M. A., Slipchenko, L. V., and Shepson, P. B.: The acid-catalyzed hydrolysis of an $\alpha$-pinene-derived organic nitrate: kinetics, products, reaction mechanisms, and atmospheric impact, Atmos. Chem. Phys., 16, 15425-15432, https://doi.org/10.5194/acp-1615425-2016, 2016.

Rollins, A. W., Fry, J. L., Hunter, J. F., Kroll, J. H., Worsnop, D. R., Singaram, S. W., and Cohen, R. C.: Elemental analysis of aerosol organic nitrates with electron ionization highresolution mass spectrometry, Atmos. Meas. Tech., 3, 301-310, https://doi.org/10.5194/amt-3-301-2010, 2010a.

Rollins, A. W., Smith, J. D., Wilson, K. R., and Cohen, R. C.: Real time in situ detection of organic nitrates in atmospheric aerosols, Environ. Sci. Technol., 44, 5540-5545, https://doi.org/10.1021/es100926x, 2010b.

Rollins, A. W., Browne, E. C., Min, K. E., Pusede, S. E., Wooldridge, P. J., Gentner, D. R., Goldstein, A. H., Liu, S., Day, D. A., Russell, L. M., and Cohen, R. C.: Evidence for $\mathrm{NO}_{x}$ control over nighttime SOA formation, Science, 337, 1210-1212, https://doi.org/10.1126/science.1221520, 2012.
Russell, L. M., Bahadur, R., and Ziemann, P. J.: Identifying organic aerosol sources by comparing functional group composition in chamber and atmospheric particles, P. Natl. Acad. Sci. USA, 108, 3516-3521, https://doi.org/10.1073/pnas.1006461108, 2011.

Saunders, S. M., Jenkin, M. E., Derwent, R. G., and Pilling, M. J.: Protocol for the development of the Master Chemical Mechanism, MCM v3 (Part A): tropospheric degradation of nonaromatic volatile organic compounds, Atmos. Chem. Phys., 3, 161-180, https://doi.org/10.5194/acp-3-161-2003, 2003.

Schwantes, R. H., Teng, A. P., Nguyen, T. B., Coggon, M. M., Crounse, J. D., St Clair, J. M., Zhang, X., Schilling, K. A., Seinfeld, J. H., and Wennberg, P. O.: Isoprene $\mathrm{NO}_{3}$ Oxidation Products from the $\mathrm{RO}_{2}+\mathrm{HO}_{2}$ Pathway, J. Phys. Chem. A, 119, 10158-10171, https://doi.org/10.1021/acs.jpca.5b06355, 2015.

Shepson, P. B., Mackay, E., and Muthuramu, K.: Henry's law constants and removal processes for several atmospheric betahydroxy alkyl nitrates, Environ. Sci. Technol., 30, 3618-3623, https://doi.org/10.1021/Es960538y, 1996.

Shiraiwa, M. and Seinfeld, J. H.: Equilibration timescale of atmospheric secondary organic aerosol partitioning, Geophys. Res. Lett., 39, L24801, https://doi.org/10.1029/2012gl054008, 2012.

Slade, J. H.: Dataset for "Nitrate radical oxidation of $\gamma$-terpinene: hydroxy nitrate, total organic nitrate, and secondary organic aerosol yields", https://doi.org/10.4231/R7CZ35BD, 2017.

Song, C., Na, K. S., and Cocker, D. R.: Impact of the hydrocarbon to $\mathrm{NO}_{x}$ ratio on secondary organic aerosol formation, Environ. Sci Technol., 39, 3143-3149, https://doi.org/10.1021/es0493244, 2005.

Spittler, M., Barnes, I., Bejan, I., Brockmann, K. J., Benter, T., and Wirtz, K.: Reactions of $\mathrm{NO}_{3}$ radicals with limonene and alphapinene: Product and SOA formation, Atmos. Environ., 40, S116S127, https://doi.org/10.1016/j.atmosenv.2005.09.093, 2006.

Spracklen, D. V., Carslaw, K. S., Pöschl, U., Rap, A., and Forster, P. M.: Global cloud condensation nuclei influenced by carbonaceous combustion aerosol, Atmos. Chem. Phys., 11, 9067-9087, https://doi.org/10.5194/acp-11-9067-2011, 2011.

Squire, O. J., Archibald, A. T., Griffiths, P. T., Jenkin, M. E., Smith, D., and Pyle, J. A.: Influence of isoprene chemical mechanism on modelled changes in tropospheric ozone due to climate and land use over the 21st century, Atmos. Chem. Phys., 15, 5123-5143, https://doi.org/10.5194/acp-15-5123-2015, 2015.

Stocker, T. F., Qin, D., Plattner, G. K., Tignor, M., Allen, S. K., Boschung, J., Nauels, A., Xia, Y., Bex, V., and Midgley, P. M.: Climate Change 2013: the Physical Science Basis, contribution of Working Group 1 to the Fifth Assessment Report of the Intergovernmental Panel on Climate Change, Cambridge University Press, Cambridge, UK and New York, NY, USA, 2013.

Suda, S. R., Petters, M. D., Yeh, G. K., Strollo, C., Matsunaga, A., Faulhaber, A., Ziemann, P. J., Prenni, A. J., Carrico, C. M., Sullivan, R. C., and Kreidenweis, S. M.: Influence of functional groups on organic aerosol cloud condensation nucleus activity, Environ. Sci. Technol., 48, 10182-10190, https://doi.org/10.1021/es502147y, 2014.

Surratt, J. D., Gomez-Gonzalez, Y., Chan, A. W. H., Vermeylen, R., Shahgholi, M., and Kleindienst, T. E.: Organosulfate formation in biogenic secondary organic aerosol, J. Phys. Chem. A, 112, 8345-8378, https://doi.org/10.1021/jp802310p, 2008.

Tan, D., Faloona, I., Simpas, J. B., Brune, W., Shepson, P. B., Couch, T. L., Sumner, A. L., Carroll, M. A., Thornberry, 
T., Apel, E., Riemer, D., and Stockwell, W.: HO$x$ budgets in a deciduous forest: Results from the PROPHET summer 1998 campaign, J. Geophys. Res.-Atmos., 106, 24407-24427, https://doi.org/10.1029/2001jd900016, 2001.

Tsigaridis, K. and Kanakidou, M.: Secondary organic aerosol importance in the future atmosphere, Atmos. Environ., 41, 46824692, https://doi.org/10.1016/j.atmosenv.2007.03.045, 2007.

Valorso, R., Aumont, B., Camredon, M., Raventos-Duran, T., Mouchel-Vallon, C., Ng, N. L., Seinfeld, J. H., Lee-Taylor, J., and Madronich, S.: Explicit modelling of SOA formation from $\alpha$-pinene photooxidation: sensitivity to vapour pressure estimation, Atmos. Chem. Phys., 11, 6895-6910, https://doi.org/10.5194/acp-11-6895-2011, 2011.

Vereecken, L. and Peeters, J.: Decomposition of substituted alkoxy radical-part I: A generalized structure-activity relationship for reaction barrier heights, Phys. Chem. Chem. Phys., 11, 9062-9074, https://doi.org/10.1039/B909712K, 2009.

von Schneidemesser, E., Monks, P. S., Allan, J. D., Bruhwiler, L., Forster, P., Fowler, D., Lauer, A., Morgan, W. T., Paasonen, P., Righi, M., Sindelarova, K., and Sutton, M. A.: Chemistry and the linkages between air quality and climate change, Chem. Rev., 115, 3856-3897, https://doi.org/10.1021/acs.chemrev.5b00089, 2015.

Wangberg, I., Barnes, I., and Becker, K.-H.: Product and mechanistic study of the reaction of $\mathrm{NO}_{3}$ radicals with alpha-pinene, Environ. Sci. Technol., 31, 2130-2135, https://doi.org/10.1021/es960958n, 1997.

Xiong, F., McAvey, K. M., Pratt, K. A., Groff, C. J., Hostetler, M. A., Lipton, M. A., Starn, T. K., Seeley, J. V., Bertman, S. B., Teng, A. P., Crounse, J. D., Nguyen, T. B., Wennberg, P. O., Misztal, P. K., Goldstein, A. H., Guenther, A. B., Koss, A. R., Olson, K. F., de Gouw, J. A., Baumann, K., Edgerton, E. S., Feiner, P. A., Zhang, L., Miller, D. O., Brune, W. H., and Shepson, P. B.: Observation of isoprene hydroxynitrates in the southeastern United States and implications for the fate of $\mathrm{NO}_{x}$, Atmos. Chem. Phys., 15, 11257-11272, https://doi.org/10.5194/acp-1511257-2015, 2015.
Xiong, F., Borca, C. H., Slipchenko, L. V., and Shepson, P. B.: Photochemical degradation of isoprene-derived 4,1-nitrooxy enal, Atmos. Chem. Phys., 16, 5595-5610, https://doi.org/10.5194/acp-16-5595-2016, 2016.

$\mathrm{Xu}$, L., Suresh, S., Guo, H., Weber, R. J., and Ng, N. L.: Aerosol characterization over the southeastern United States using high-resolution aerosol mass spectrometry: spatial and seasonal variation of aerosol composition and sources with a focus on organic nitrates, Atmos. Chem. Phys., 15, 7307-7336, https://doi.org/10.5194/acp-15-7307-2015, 2015.

Yeh, G. K. and Ziemann, P. J.: Alkyl nitrate formation from the reactions of $\mathrm{C}_{8}-\mathrm{C}_{14} n$-alkanes with $\mathrm{OH}$ radicals in the presence of $\mathrm{NO}_{x}$ : measured yields with essential corrections for gas-wall partitioning, J. Phys. Chem. A, 118, 8147-8157, https://doi.org/10.1021/jp500631v, 2014.

Zhang, X., Cappa, C. D., Jathar, S. H., Mcvay, R. C., Ensberg, J. J., Kleeman, M. J., and Seinfeld, J. H.: Influence of vapor wall loss in laboratory chambers on yields of secondary organic aerosol, P. Natl. Acad. Sci. USA, 111, 5802-5807, https://doi.org/10.1073/pnas.1404727111, 2014.

Ziemann, P. J. and Atkinson, R.: Kinetics, products, and mechanisms of secondary organic aerosol formation, Chem. Soc. Rev., 41, 6582-6605, https://doi.org/10.1039/C2CS35122F, 2012. 